\title{
Hääle spektri mähiskõvera kuju stabiilsus varieeruva dünaamikaga heliredelite laulmisel
}

\author{
Allan Vurma \\ Eesti Muusika- ja Teatriakadeemia vanemteadur \\ vurma@ema.edu.ee
}

\begin{abstract}
Teesid: Käesoleva töö eesmärk oli uurida, kas ja kuidas muutuvad klassikaliselt treenitud lauljate hääle tämbriga seotud akustilised parameetrid, kui laulda hääle dünaamikat ja helikõrgust muutes. Uurimust motiveeris läbi viima vokaalpedagoogilises kirjanduses sageli väljendatud seisukoht, et klassikalise laulutreeningu üks eesmärk on hääle kõlalise ühtluse saavutamine. Palusime kümnel meeslauljal (kelle hulgas olid ooperi- ja oratooriumisolistid ning laulueriala üliõpilased) laulda ühe oktavi ulatusega tõusvaid $D$-duuri gammasid (vahemikus $d-d^{1}$ ) kolmel moel: (1) kõige harjumuspärasema dünaamikaga, (2) häälevaljust kasvatades ja (3) häälevaljust kahandades. Salvestasime esitused väikese reverberatsiooniga helistuudios. Tarkvara Sopran 1.0.10 abil arvutasime iga lauldud noodi keskmise võimsusspektri, kus määrasime põhitooni ja lauljaformandi spektripiirkondade tugevused spektri kõige tugevama tipu taseme suhtes. Mõõtsime iga lauldud noodi puhul ka helirõhu taseme ja glotaalse aduktsiooni tugevust iseloomustavate sulguskvotsiendi ja kvaasikontaktkvotsiendi väärtused. Uuringutulemused näitasid, et vastavad parameetrid muutusid ülesannete täitmisel süstemaatiliselt kõigi lauljate puhul. Osa kirjeldatud muutustest tingisid puht-akustilised faktorid, mida vokalist ei saa vokaaltehnikaga mõjutada. Mõni laulja kasutas vokaaltehnilisi võtteid, mille eesmärgiks võis olla häälekõla tajutava ühtluse parandamine. Üks taolisi võtteid oli piano ja forte vahelise erinevuse tekitamine eelkõige hääle tämbri, mitte aga niivõrd otsese helirõhu taseme abil. Vastupidiseks strateegiaks oli just helirõhu taseme muutmine, samal ajal hääletämbri kanduvuse ja ereduse aspektiga seotud lauljaformandi suhtelise tugevuse varieerumist väiksena hoides. Hääle tajutav ühtlus võib olla seotud veel hääle mõningate omadustega, mida käesolevas töös lähemalt ei käsitletud. Hääleparameetrite väärtuste varieerumise viis sõltuvalt helikõrgusest ja dünaamikast võib oleneda ka häälikust, mida laulmisel kasutatakse ning helikõrguse piirkonnast.
\end{abstract}

Märksõnad: glotograafia, hääle dünaamika, hääle ühtlus, klassikaline laulmine, lauljaformant, pöördfiltreerimine, spektraalne analüüs 


\section{Sissejuhatus}

Klassikalise laulukoolituse üks eesmärke on hääletooni või -tämbri ühtlus üle hääle kõrgusliku ja dünaamilise ulatuse (Christy 1967; Hemsley 1998; Scearce 2016; Miller 1996). Püsivalt kestva nn statsionaarse heli puhul sõltub selle tämber eelkõige helispektri mähiskõvera kujust (Heller 2012). Vastavalt Gunnar Fanti (1960) hääleproduktsiooni allikas-filter teooriale on hääle akustilised omadused määratud (1) häälekurdude võnkumislaadiga, mis tekitab nn alghääle (ingl k voice source) ning (2) vokaaltrakti kuju ja suurusega. Vokaaltrakt koosneb suu- ja neeluõõnest ning toimib filtrina, mis tugevdab neid alghääle spektrikomponente, mille sagedus langeb vokaaltrakti resonantssageduste e. formantide lähedusse. Kaks madalamat formanti F1 ja F2 määravad põhiliselt vokaali kvaliteedi, kõrgemad formandid aga pigem hääle isikupärase tämbri (Sundberg 1987). Klassikaliselt koolitatud lauljad (v.a ehk sopranid) kasutavad sageli vokaaltehnikat, mille puhul liginevad üksteisele kõrgemate formantide sagedused (F3, F4 ja F5) ning moodustub üks tugevnenud nn lauljaformant (Sundberg 1974). Lauljaformandi esinemine hääle spektris mõjutab hääle tämbrit - hääl muutub säravamaks ja kandvamaks (ibid.). Ka madalamad formandid muutuvad tugevamaks, kui nende vahekaugus väheneb (Fant 1960; Sundberg 2013).

Häälekurdude töörežiimi iseloomustab glotaalne aduktsioon, ehk jõud, millega häälepaelu ligindatakse üksteisele võnkumise ajal (Sundberg 2013). Aduktsiooni tugevusega seotud parameeter on sulguskvotsient (CQ), mis näitab ajalist proportsiooni terves võnketsüklis, mil häälepilu on suletud (Titze 1994). Analoogne parameeter on kvaasikontaktkvotsient QxEGG, mis näitab häälepaelte omavahel kontaktis oleku aja proportsiooni ja mida saab mõõta larüngograafi abil (Herbst \& Ternström 2006). Fonatsiooni tüüp saab varieeruda kujuteldaval skaalal "kahinafonatsioon - pressitud fonatsioon". Kahinafonatsiooni puhul on häälepilu kokku viiv jõud nii nõrk, et häälepilu ei sulgugi päris täielikult. Hääl võib kõlada siis kahisevalt, alghääle spektris on põhitooni komponent tugev, kuid kõrgemad osahelid on nõrgad. Pressitud fonatsiooni korral on aga häälepilu kokku viiv jõud suur ja häälepilu suletud oleku aeg pikk. Alghääle spektris on sel juhul spektri põhitooni komponent suhteliselt nõrk, kuid kõrgemad osahelid tugevad. (Sundberg 2013)

Sundbergi (1987) väitel paikneb klassikaliselt koolitatud laulja jaoks optimaalne fonatsioonitüüp kahe äärmuse vahel, kusagil skaala keskosast pehmema fonatsiooni suunas. Taolise nn "voolava fonatsiooni" puhul on mingi kindla häälepaelte aluse rõhu juures genereeritav helivõimsus maksimaalne, samuti on siis hääle spektris samal ajal tugevad nii põhitoon kui ka kõrgemad osahelid. Kirjandusest võib leida seisukohti, et hääle ühtluse saavutamiseks 
tuleks kasutada sellist vokaaltehnikat, mis tagaks CQ väärtuse stabiilsuse hoolimata sooritatavast vokaalsest ülesandest, nt hääletugevuse paisutamisel või kahandamisel (Titze \& Abbott 2012: 278; Björkner et al. 2006).

Käesoleva töö eesmärk on uurida, kas ja kuidas muutub klassikaliselt koolitatud lauljate hääletämber, kui lauljal tuleb muuta nii hääle kõrgust kui ka dünaamikat, paari konkreetse vokaalse ülesande näitel. Püüame analüüsida, millised mehhanismid võivad tekitada hääletämbri muutumist ning välja selgitada, kas lauljad kasutavad mingeid konkreetsemaid vokaaltehnilisi võtteid, et selliste ülesannete täitmisel hääletämbri võimalikku varieerumist parema hääle ühtluse saavutamiseks vähendada.

Tavaliselt reguleeritakse hääle tugevust häälepaelte aluse õhurõhu muutmise teel (Sundberg 1990; Gauffin \& Sundberg 1989), ehki seda võivad mõjutada ka muud faktorid nagu glotaalse aduktsiooni tugevus (Zhang 2016) ja häälespektri osahelide kaugus formantsagedusest, sest formandi võimendav mõju osaheli tugevusele on suur vastavate sageduste kokkulangemisel ja väiksem, kui vastav distants on suurem (Sundberg 2013). Eriti oluline on siin esimene formant, sest selle ligiduses paiknev osaheli on tavaliselt spektris tugevaim ja määrab seetõttu põhiliselt ka terve heli helirõhu taseme (Sundberg et al. 1993; Gramming \& Sundberg 1988; Titze 1992; Gauffin \& Sundberg 1989).

Fonatsioonil läbi häälepilu kulgevad õhuimpulsid on oma kujult üldjuhul veidi paremale viltu, sest õhu inertsuse tõttu toimub häälepilu sulgumine kiiremini kui selle avanemine. Suurem häälepaelte alune õhurõhk (valjemalt laulmine) tekitab suurema amplituudiga viltusemad impulsid. Suurem ebasümmeetria tähendab seda, et alghääle spektri kalle muutub väiksemaks (st viltusemate impulsside korral on kõrgemad osahelid suhteliselt tugevamad). Õhuimpulsside viltusus võib oleneda ka hääle kõrgusest. See muutub väiksemaks kõrgemate nootide laulmisel, kui põhitooni komponent spektris liigub lähemale vokaaltrakti esimesele formandile, ja on seotud vokaaltrakti impedantsi muutumisega. (Sundberg et al. 1993)

Mitmete autorite andmetel (Lã \& Sundberg 2015; Salomao \& Sundberg 2008), esineb tugev korrelatsioon CQ (aga samuti ka QxEGG) ja hääleallika spektri põhitooni komponendi tugevuse vahel. Uuringud (Herbst et al. 2015) on näidanud, et klassikalise häälekoolituse läbinud isikud suudavad reguleerida erinevaid hääletekitamise mehhanismi aspekte (nt häälepaelte aluse õhurõhu suurus ja glotaalse aduktsiooni tugevus) iseseisvatena, kuid vokaalselt treenimata isikute puhul kalduvad vastavate aspektide muutused üksteisest sõltuma. Klassikalisel hääletreeningul õpivad lauljad reguleerima ka hääletekitamise fonatoorset (st häälepaelte tööga seotud) ja artikulatoorset (vokaaltrakti kujuga seotud) aspekti nii, et erinevate häälikute artikuleerimine ei tingiks tahtmatuid muutusi fonatsioonis (Scearce 2016). 
Kõrisignaali (alghäält) pole võimalik registreerida ega uurida otseste meetoditega. Seda saab siiski teha kaudselt, näiteks kasutades suust väljuva häälesignaali pöördfiltreerimist (inverse filtering) või häälepilu elektrilise takistuse muutumise registreerimist larüngograafi abil.

Pöördfiltreerimisel rakendatakse tagurpidi pööratud vokaaltrakti ülekandefunktsioon häälesignaalile, mille tulemusena saadakse jälle kõrisignaal. Tulemus oleneb aga üsna palju protseduuri teostaja subjektiivsetest valikutest formantsageduste määramisel. Samuti pole välistatud artefaktide esinemine ning isegi teoreetiliselt puudub võimalus hinnata meetodi täpsust (Gobl \& Ni Chasaide 2012). Ka larüngograafi signaali põhjal tehtavate järelduste puhul pole võimalik elimineerida nende teatud ebakindlust, sest graafiku kuju, mis on iseloomulik häälepilu sulgumisele, võib esineda ka siis, kui täielikku sulgumist ei toimugi (Colton \& Conture 1990). Võimalik on veel häälekurdude võnkumise otsene vaatlemine endoskoobi abil ja häälepilu ava pindala muutumise mõõtmine, kuid protseduur on katseisikule ebamugav ja häirib loomulikku laulmist (Titze \& Abbott 2012) ning kaamera vaatevälja ei pruugi alati ulatuda kõri tervikuna. Ka selle meetodi puhul saab kõrisignaali enda kohta teha vaid kaudseid oletusi, sest õhu inertsuse tõttu ei vasta õhuvoolu kiiruse hetkväärtus päris üksüheselt kõriava suurusele samal hetkel (Granqvist et al. 2003).

\section{Meetod}

Kümnel klassikaliselt treenitud meeslauljal, kelle hulka kuulusid nii elukutselised vokalistid kui ka laulueriala üliõpilased, ja kelle vanus oli vahemikus 23-60 aastat (keskmine 29,8), paluti laulda tõusev $D$-duur heliredel ( $d$-st kuni $d^{1}$-ni) vokaalil /a/ kolmel moel. Esimesel korral tuli laulda kõige harjumuspärasemat ja mugavamat dünaamikat kasutades, püüdmata spetsiaalselt muuta ülesande jooksul hääle dünaamikat ( $f$ - $f$ ülesanne). Teisel korral paluti alustada laulmist pianos ning jätkata crescendos kuni forteni ( $p-f$ ülesanne). Kolmandal korral oli ülesanne vastupidine: alustada fortes ja teha oktavi jooksul diminuendo pianoni ( $f-p$ ülesanne). Palusime lauljatel kujutleda end reaalsesse olukorda ooperi- või kontserdilaval ja laulda nii, nagu vastavad ülesanded oleks osa nende partiist või kontserdiprogrammist.

Esitused salvestati portatiivse helisalvesti ZOOM H6 ja ringdiagrammiga mikrofoni DPA 4061 abil väikese reverberatsiooniajaga (T30 = $0.2 \mathrm{~s}$ ) Eesti Muusika- ja Teatriakadeemia helistuudios. Ligikaudu 6-7 cm kaugusel laulja suunurgast paiknev mikrofon oli kinnitatud peavõru külge, mis tagas selle positsiooni stabiilsuse. Kvantimissagedus salvestamisel oli 44100 Hz. Paralleelselt heliga registreeriti ka larüngograafi signaal seadmega Laryngograph D200 ja 
tarkvaraga Speech Studio 4.1. Selleks, et võimaliku kõri vertikaalse asendi muutumise korral laulmisel tagada signaali stabiilsus, kasutasime ovaalseid elektroode, mis kinnitati elastse paelaga katseisiku kaelale kahele poole kõri.

Salvestusprotsessis kasutasime lisaks veel teist mikrofoni ( $A K G C K 77$ ), mis paiknes larüngograafi elektroodide juhtme küljes umbes $20 \mathrm{~cm}$ kaugusel laulja suuavast ja oli vajalik tarkvara Speech Studio 4.1 tööks. Selle mikrofoni signaali kasutasime ka helirõhu taseme (SPL) mõõtmiseks. Mikrofonisignaali salvestustaseme kalibreerisime $1000 \mathrm{~Hz}$ võnkesagedusega siinusheli ja helitaseme mõõturi UNI-T UT352 abil. Helitaseme mõõturi mikrofoni ja kalibreeritava mikrofoni asetasime kalibreerimisel teineteise kõrvale. Kasutasime dBC skaalat, sest see vastab paremini kuid dBA skaala suhteliselt valjude helide tajumisele, mida tüüpiliselt produtseerivad klassikaliselt koolitatud lauljad. Helirõhu tasemed arvutasime ümber kaugusele $30 \mathrm{~cm}$, võttes arvesse, et helirõhu tase sõltub pöördvõrdeliselt heliallikast kauguse ruuduga (Hartmann 2013). Tulemuste esitamisel kasutame iga noodi puhul nn ekvivalentse helirõhu taseme $\left(\mathrm{L}_{\text {ekv }}\right)$ väärtusi, mis iseloomustavad keskmist SPLi üle vastava noodi kestuse. Salvestatud esituste igale noodikõrgusele vastavat heli analüüsisime akustiliselt vabavara Sopran 1.0.10 abil (arendatud Stockholmi KTH-s Svante Granquisti poolt, http://www.tolvan.com/index.php?page=/sopran/sopran. php, vaadatud 22.06.2017). Mõõtsime iga lauldud noodi võimsusspektri, mis oli keskmistatud üle noodikestuse kvaasistatsionaarse osa (kasutasime Blackmani akent ribalaiusega $50 \mathrm{~Hz}$ ja pikkusega $80 \mathrm{~ms}$ ). Spektripiltidelt määrasime: (1) kõige tugevama spektripiigi taseme (LF1, reeglina oli selleks piigiks osaheli, mille sagedus oli kõige lähemal lauldava vokaali esimese formandi sagedusele F1), (2) põhitoonile vastava spektripiigi (H1) helitaseme (LH1) ja (3) lauljaformandi sageduspiirkonna (ligikaudu $2-4 \mathrm{kHz}$ ) kõige tugevama spektriosa taseme (LF3, vt joonis 7, paneel vasakul ülal). Arvutasime ka väärtused LH1-LF1 ja LF3-LF1 (mis iseloomustavad suhteliselt hästi vastavalt põhitooni ja lauljaformandi tugevust heli kui terviku helirõhu taseme suhtes).

Salvestised olid teostatud ühe eelneva töö (Vurma 2017) raames, kus esitasime pöördfiltreerimise meetodi abil uuritud hääleproduktsiooni fonatoorset aspekti puudutavad tulemused. Kuna tookord ebaõnnestus ühe laulja (D) puhul larüngograafilise signaali registreerimine, arvatavasti katseisiku kõri piirkonnas adipoosse koe esinemise tõttu, siis käesolevasse töösse kaasasime täiendava katseisiku (K, bass, vanus 33 a, rahvusvahelise kogemusega ooperisolist) salvestised katseisik D salvestiste asemel. Siinses töös esitatud tulemused $\mathrm{L}_{\text {ekv }}$ ja $\mathrm{CQ}$ muutumise kohta on oma sisult ekvivalentsed eelmise töö vastavate tulemustega, ehkki arvulised väärtused on veidi teistsugused, kuna üks katseisik on erinev. 


\section{Tulemused I: Grupi keskmised trendid}

\section{Laulmisel tegelikult produtseeritud helirõhu tasemed}

$f$ - $f$ ülesandes kaheksa tõusva helirea astme laulmise jooksul suurenes kümne laulja keskmine $\mathrm{L}_{\text {ekv }}$ väärtus 9,7 dB võrra 92,3 dB-st kuni $102 \mathrm{~dB}$-ni (mõõdetuna $30 \mathrm{~cm}$ kaugusel laulja suuavast). See tähendab, et helirõhu tase muutus tõusva heliredeli laulmisel suuremaks isegi siis, kui lauljad ei püüdnud teadlikult laulda järjest valjemalt (vt ka joonis 1). Standardhälve jäi kõikide noodikõrguste puhul piiridesse 5 kuni $6 \mathrm{~dB}$. Crescendo $(p-f)$ ülesandes suurenes $\mathrm{L}_{\mathrm{ekv}}$ väärtus keskmiselt 20,5 dB võrra 84,1 dB-st 104,6 dB-ni. Standardhälve oli veidi suurem madalate vaikselt lauldud nootide puhul ja väiksem, kui lauldi kõrgeid noote valjult, paiknedes vahemikus 7,7 ja $4,2 \mathrm{~dB}$. Diminuendo $(f-p)$ ülesande laulmisel keskmine helirõhu tase küll vähenes, aga vaid $2,8 \mathrm{~dB}$ võrra 96,7 dB-st kuni 93,9 dBni. Mõnel lauljal suurenes koos kõrgusega tegelik helirõhu tase ka selle ülesande puhul. Seetõttu ulatus standardhälve kõrgete nootide laulmisel siin väärtuseni $8,8 \mathrm{~dB}$, aga oli umbes poole madalam madalate valjult lauldud nootide puhul.

Joonis 1. Kümne katseisiku keskmised ekvivalentse helirõhu taseme väärtused (koos standardhälvetega) sõltuvalt helirea astmekõrgusest (väärtused on mõodetud iga noodikõrguse kvaasistatsionaarse osa lõikes).

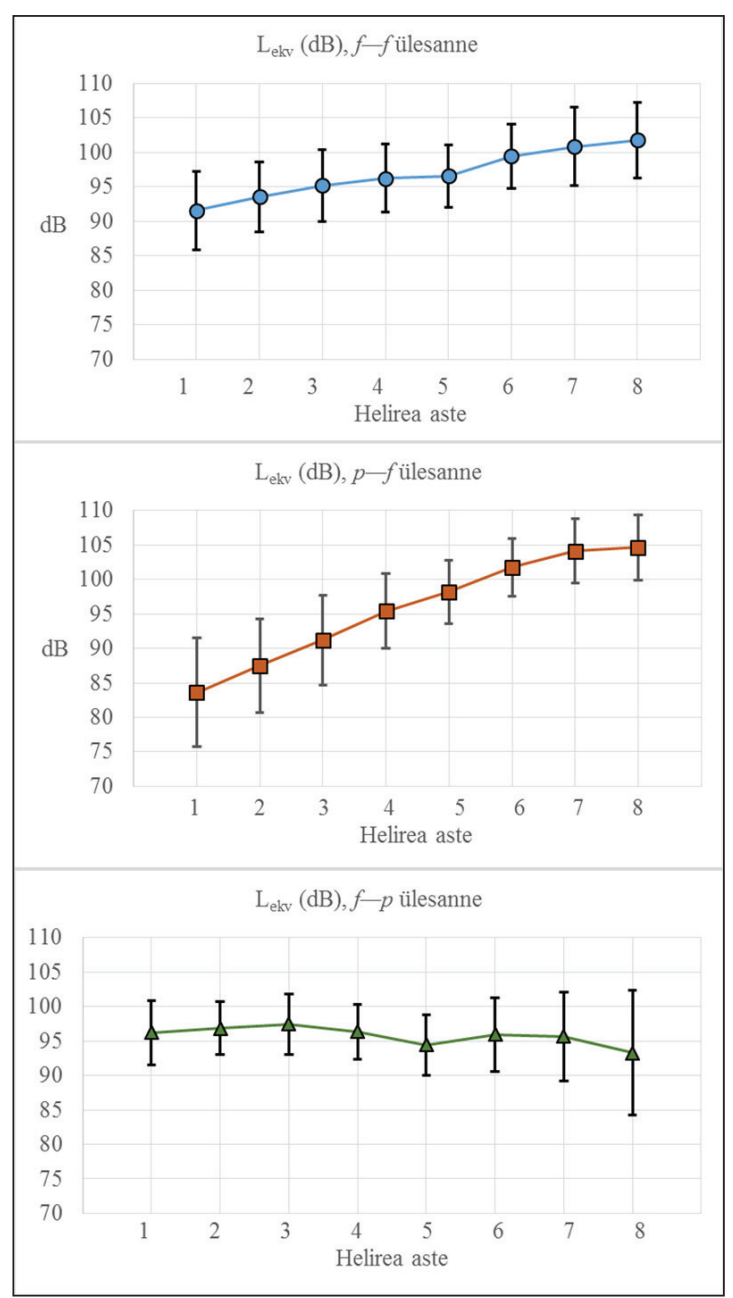




\section{Häälepaelte pressitus (CQ ja QxEGG)}

Tarkvara Speech Studio 4.1, mida kasutasime QxEGG väärtuste mõõtmiseks, loeb häälepilu oleku suletuks, kui larüngograafi signaali tase on tõusnud 30 protsendini signaali miinimum-ja maksimumväärtuse vahelisest (peak-to-peak) amplituudi väärtusest. (Signaali madalad väärtused vastavad suurele elektrilisele takistusele ehk häälepilu avatud olekule ja kõrged väärtused madalale elektrilisele takistusele ehk tugevale häälepaelte omavahelisele kontaktile.) Selliselt määratud $Q x E G G$ väärtuste ja pöördfiltreerimisel leitud $C Q$ väärtuste vahel esines tugev positiivne korrelatsioon $(r=0,82)$. Absoluutskaalal olid QxEGG väärtused $C Q$ väärtustega võrreldes siiski ligikaudu kümne protsendipunkti võrra kõrgemad, näidates mõnevõrra pikemat häälepilu suletud oleku aega (joonis 2). Nii CQ kui QxEGG väär-

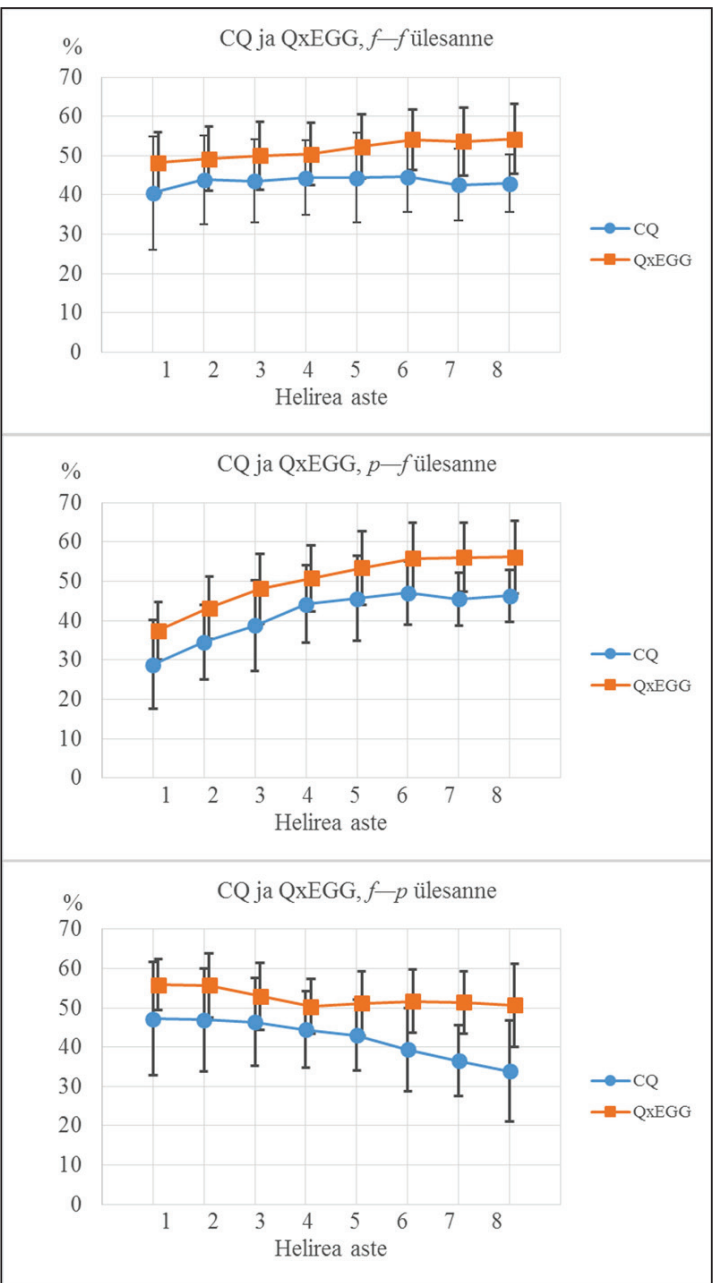
tused kaldusid olema madalamad (st häälepilu suletud oleku aeg võnketsüklis oli lühike), kui madalaid helikõrgusi tuli laulda vaikselt, ning vastavad väärtused olid kõrged kõrgete nootide laulmisel valjult. Ka madalalt ja valjult lauldes $(f-p$ ülesandes) olid CQ ja QxEGG väärtused kõrged (viidates tugevale aduktsioonile). Kõrgelt ja vaikselt lauldes aga oli individuaalne varieeruvus suur. Kuigi sel puhul keskmiselt CQ ja QxEGG väärtused langesid, leidus mitu lauljat, kelle puhul selget langust ei esinenud või tekkis hoopis vastavate väärtuste tõus.

Joonis 2. Kümne laulja keskmised CQ ja QxEGG väärtused sõltuvalt helirea astmekõrgusest koos standardhälvetega. 


\section{Põhitooni suhteline tugevus (LH1-LF1)}

Põhitoon kaldus olema tugevam, kui madalaid noote lauldi vaikselt. Kõrgete vaikselt lauldud nootide puhul oli individuaalne varieeruvus suur, kuid kui kõrgeid noote lauldi valjult, põhitoon veidi nõrgenes (vt joonis 3).

Vastavalt paarisvõrdluse $t$-testi tulemustele olid eelpoolkirjeldatud tendentsid statistiliselt olulised (tabel 1), välja arvatud helirea esimese ja kaheksanda astmekõrguse vahel $f-p$ ülesandes, kus vaikse kõrge noodi puhul esines suur individuaalne varieeruvus.

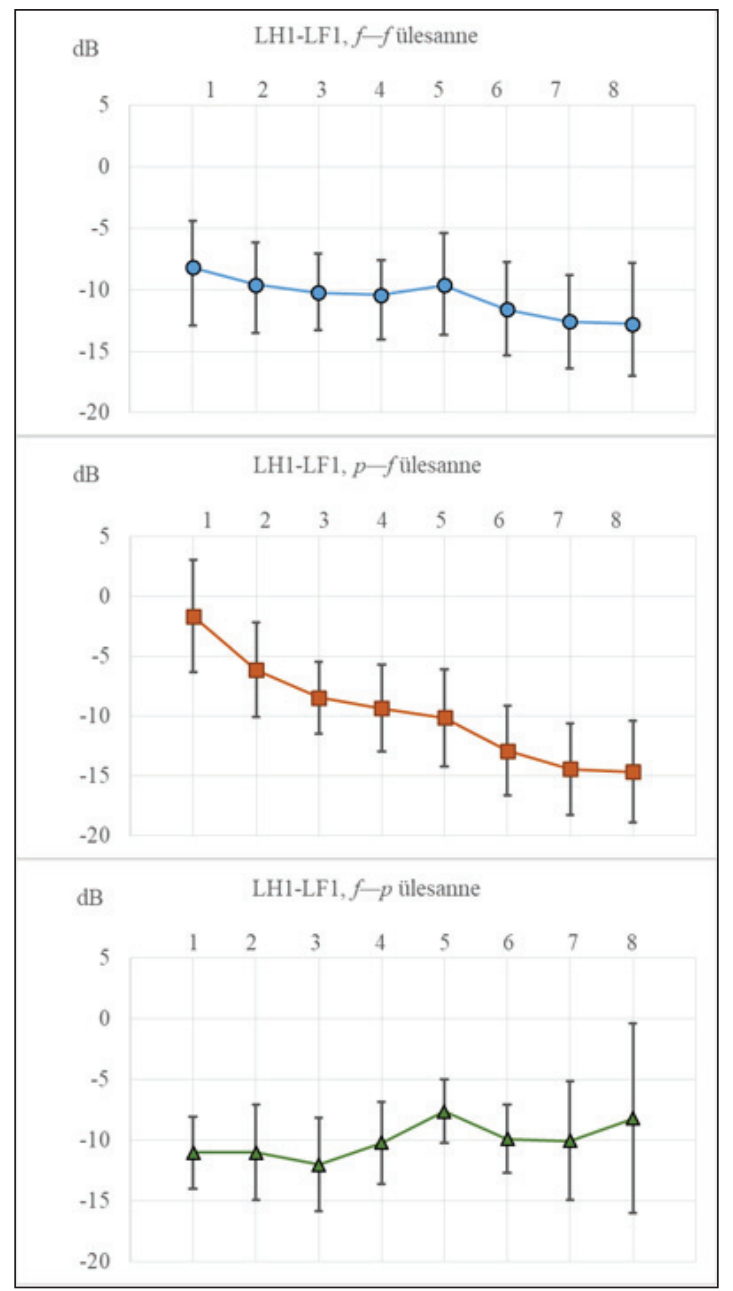

Joonis 3. Kümne laulja keskmised LH1-LF1 (põhitooni suhtelise tugevuse) väärtused sõltuvalt helirea astmekõrgusest koos standardhälvetega. 
Tabel 1. LH1-LF1 (põhitooni suhtelise tugevuse) väärtuste erinevuse statistiline olulisus paarisvõrdluse t-testi tulemuste põhjal helirea esimese (\#1) ja viimase (\#8) astme laulmisel.

\begin{tabular}{|c|c|c|c|c|c|c|}
\hline \multicolumn{4}{|c|}{ LH1-LF1 [dB] } & \multicolumn{3}{|c|}{ Paarisvõrdluse $t$-test } \\
\hline Ülesanne & Aste & Ülesanne & Aste & $t$ & $d f$ & $P$ (paaris) \\
\hline \multirow[t]{2}{*}{$f-f$} & $\# 1$ & $f-f$ & $\# 8$ & & & \\
\hline & $-8,2$ & & $-12,8$ & $-4,81$ & 9 & 0,0005 \\
\hline \multirow[t]{2}{*}{$p-f$} & $\# 1$ & $p-f$ & \#8 & & & \\
\hline & $-1,65$ & & $-14,64$ & $-8,4$ & 9 & 0,000 \\
\hline \multirow[t]{2}{*}{$f-p$} & $\# 1$ & $f-p$ & \#8 & & & \\
\hline & $-11,02$ & & $-8,21$ & 1,27 & 9 & 0,24 \\
\hline \multirow[t]{2}{*}{$p-f$} & $\# 1$ & $f-p$ & $\# 1$ & & & \\
\hline & $-1,65$ & & $-11,02$ & $-6,96$ & 9 & 0,000 \\
\hline \multirow[t]{2}{*}{$p-f$} & $\# 8$ & $f-p$ & \#8 & & & \\
\hline & $-14,64$ & & $-8,21$ & 4,31 & 9 & 0,002 \\
\hline \multirow[t]{2}{*}{$p-f$} & $\# 1$ & $f-p$ & $\# 8$ & & & \\
\hline & $-1,65$ & & 8,21 & $-3,05$ & 9 & 0,014 \\
\hline \multirow[t]{2}{*}{$p-f$} & $\# 8$ & $f-p$ & $\# 1$ & & & \\
\hline & $-14,64$ & & $-11,02$ & 2,49 & 9 & 0,035 \\
\hline
\end{tabular}

Märkus: Paksus kirjas on esitatud juhud, mille puhul erinevus on statistiliselt oluline $(P<0,05)$.

\section{Lauljaformandi suhteline tase (LF3-LF1)}

LF3-LF1 väärtus (joonis 4) iseloomustab lauljaformandi sageduspiirkonna prominentsust hääle spektris. Vaikselt laulmisel kaldus lauljaformant olema nõrgem. Ka päris kõrgete nootide (seitsmenda ja kaheksanda astmekõrguse) puhul kippus lauljaformandi tugevus kahanema isegi siis kui lauldi crescendos. $f-f$ ülesande puhul oli lauljaformandi sagedusalas $(2-4 \mathrm{kHz})$ paikneva tugevaima spektritipu tase keskmiselt 15 dB nõrgem LF1-st kõigi helirea esimese kuue astme laulmisel. Kahe kõige ülemise astmekõrguse laulmisel langes vastav tasemete erinevus järkjärgult kuni -19 dB-ni. See langus, mõõdetuna kuuenda 


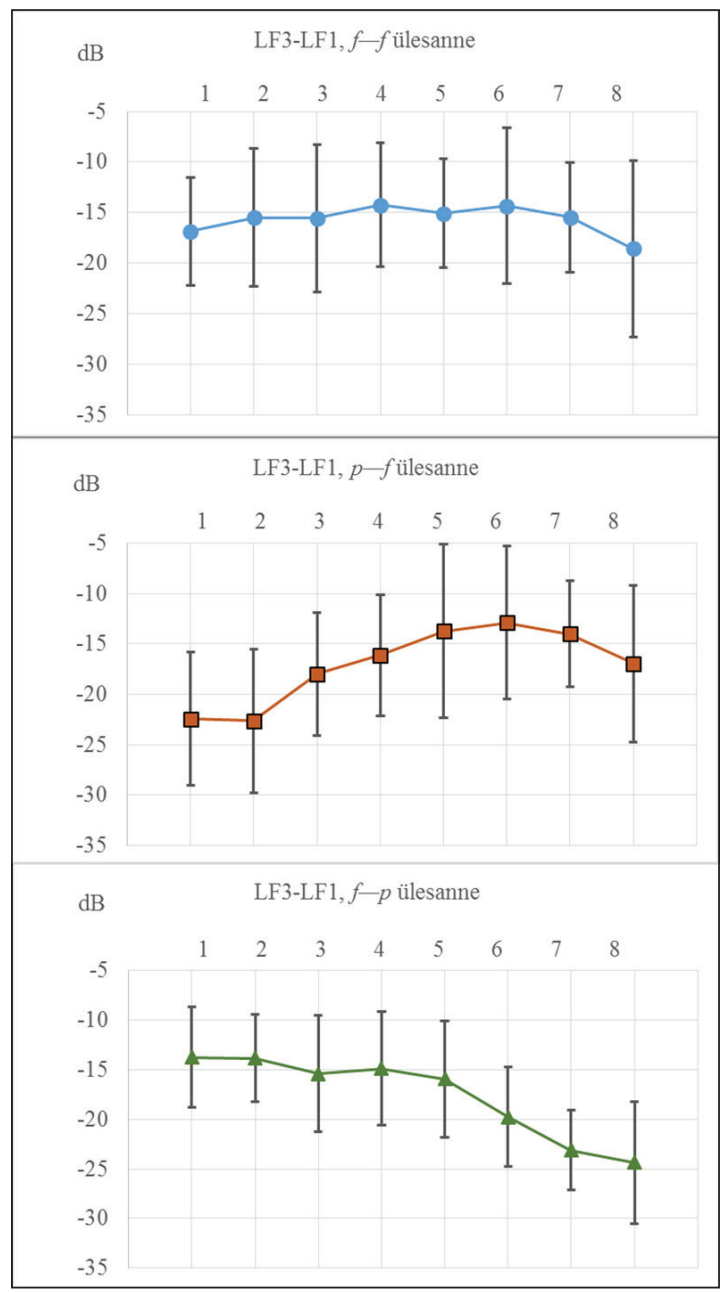

Joonis 4. Kümne laulja keskmised LF3-LF1 (lauljaformandi suhtelise tugevuse) väärtused sõltuvalt helirea astmekõrgusest koos standardhälvetega.

ja kaheksanda helirea astme vahel, oli paarisvõrdluse $t$-testi tulemuste põhjal statistiliselt oluline $(t=-2,95(9), P($ kahepoolne $)=0,016)$.

$p-f$ ülesandes oli LF3-LF1 keskmine väärtus $-22 \mathrm{~dB}$ helirea kahe madalaima astme puhul ja hakkas siis suurenema kuni -13 dB-ni kuuenda astme laulmisel. Sealt alates toimus järkjärguline langus kuni väärtuseni $-17 \mathrm{~dB}$ kaheksanda astmekõrguse juures. Erinevus LF3-LF1 väärtustes kuuenda ja kaheksanda astme puhul oli statistiliselt oluline (paarikaupa $t$-test, $t=-3,26$ (9), P(kahepoolne $)=0,01)$. 


\section{Korrelatsioonid}

Arvutasime Pearsoni korrelatsioonikordajad mõõdetud hääle spektraalsete parameetrite ja mõningate teiste hääleaparaadi toimimist iseloomustavate parameetrite vahel (vt tabel 2). Näeme, et korrelatsioon aduktsiooni tugevust iseloomustava CQ ja põhitooni prominentsust iseloomustava LH1-LF1 vahel $(r=-0,63)$ on palju tugevam kui CQ ja lauljaformandi prominentsust iseloomustava LF3-LF1 vahel $(r=0,21)$. See kehtib ka sel juhul, kui CQ asemel arvutada korrelatsioon QxEGG-ga. Sarnaselt on korrelatsioon tugev (ja negatiivne) LH1-LF1 ja SPL vahel $(r=-0,69)$, kuid vaid mõõduka tugevusega LF3-LF1 ja SPL vahel $(r=0,42)$.

Spektraalsete parameetrite korrelatsioon heli kõrgusega (lauldava noodi heliredeli astmepositsiooniga) on palju tagasihoidlikum. Astmepositsiooni ja LH1-LF1 vaheline korrelatsioon on nõrk ja negatiivne $(r=-0,31)$ ning astmepositsiooni ja LF3-LF1 vaheline korrelatsioon on tühiselt väike.

Korrelatsioonikordaja väärtus iseloomustab küll seoste tugevust, kuid ei anna informatsiooni kausaalsuse kohta. Võime siiski väita, et glotaalse aduktsiooni tugevus väljendub kõlaliselt eelkõige spektri põhitoonis (põhitoon on tugevam nõrga aduktsiooni korral) ja mitte sedavõrd lauljaformandi tasemes. LF3-LF1 väärtus oleneb suurel määral ka muudest teguritest, näiteks laulja vokaaltehnika artikulatoorsest aspektist, samuti hääleliigiga seotud individuaalsest vokaalaparaadi morfoloogiast (Sundberg 2001). Seetõttu ei pruugi pressitumalt laulmine olla just kõige efektiivsem strateegia hääletämbri säravuse saavutamiseks. Lauljal võib aduktsiooni tugevuse tahtelise kontrolli tähtsus seisneda pigem üldise hääletekitamise ning registriüleminekute ladususe ja stabiilsuse tagamises.

Tabel 2. Pearsoni korrelatsioonikordajate väärtused helirea astmepositsiooni (Aste), ekvivalentse helirõhu taseme $\left(L_{e k v}\right)$, häälepilu sulguskvotsiendi $(C Q)$, kvaasikontaktkvotsiendi (QxEGG), põhitooni suhtelise tugevuse (LH1-LF1), lauljaformandi suhtelise tugevuse (LF3-LF1) vahel ja alghääle spektri põhitooni suhtelise tugevuse (LH1-LH2).

\begin{tabular}{|l|l|l|l|l|l|l|}
\hline Parameeter & Aste & $\mathrm{L}_{\text {ekv }}$ & CQ & QxEGG & LH1-LF1 & LF3-LF1 \\
\hline $\mathrm{L}_{\text {ekv }}$ & $\mathbf{0 , 4 7}$ & & & & & \\
\hline CQ & 0,04 & $\mathbf{0 , 4 4}$ & & & & \\
\hline QxEGG & $\mathbf{0 , 2 4}$ & $\mathbf{0 , 6 1}$ & $\mathbf{0 , 7 4}$ & & & \\
\hline LH1-LF1 & $\mathbf{- 0 , 3 1}$ & $\mathbf{- 0 , 6 9}$ & $\mathbf{- 0 , 6 3}$ & $\mathbf{- 0 , 6 5}$ & & \\
\hline LF3-LF1 & $-0,06$ & $\mathbf{0 , 4 2}$ & $\mathbf{0 , 2 1}$ & $\mathbf{0 , 2 2}$ & $-0,04$ & \\
\hline LH1-H2 (alghääl) & 0,12 & $\mathbf{- 0 , 4 5}$ & $\mathbf{- 0 , 7 7}$ & $\mathbf{- 0 , 7 6}$ & $\mathbf{0 , 6 0}$ & $\mathbf{- 0 , 2 5}$ \\
\hline
\end{tabular}

Märkus: Paksus kirjas juhtudel on $P<0,000$. Selles tabelis põhinevad arvutused üheteistkümne laulja andmetel (hõlmatud on nii lauljate D kui ka K andmed, välja arvatud korrelatsioonide puhul QxEGG-ga, kus laulja D andmed puudusid). 


\section{Arutelu I: LH1-LF1 ja LF3-LF1 väärtuse muutumist põhjustanud faktorid}

Olulisemad faktorid, mis võisid põhjustada meie ülesannetes eelpoolkirjeldatud tendentse LH1-LF1 väärtuse muutumises, on esitatud tabelis 3. Kaks esimest faktorit selles tabelis on puht-akustilised ega sõltu laulja vokaaltehnikast. Faktor 1 näitab, et see, millise järjekorranumbriga osaheli satub paiknema kõige ligemale F1-le, sõltub heli kõrgusest (eeldusel, et F1 ei muutu). Meie ülesannete puhul oli helikõrguse $d$ laulmisel esimesele formandile kõige lähemal tüüpiliselt neljas osaheli, oktav kõrgemal paikneva $d^{1}$ laulmisel oli selleks aga teine osaheli (vt joonis 5). Kuna muude tingimuste võrdsuse korral on alghääle teine osaheli tugevam kui neljas, siis on tugevam ka vastav LF1.

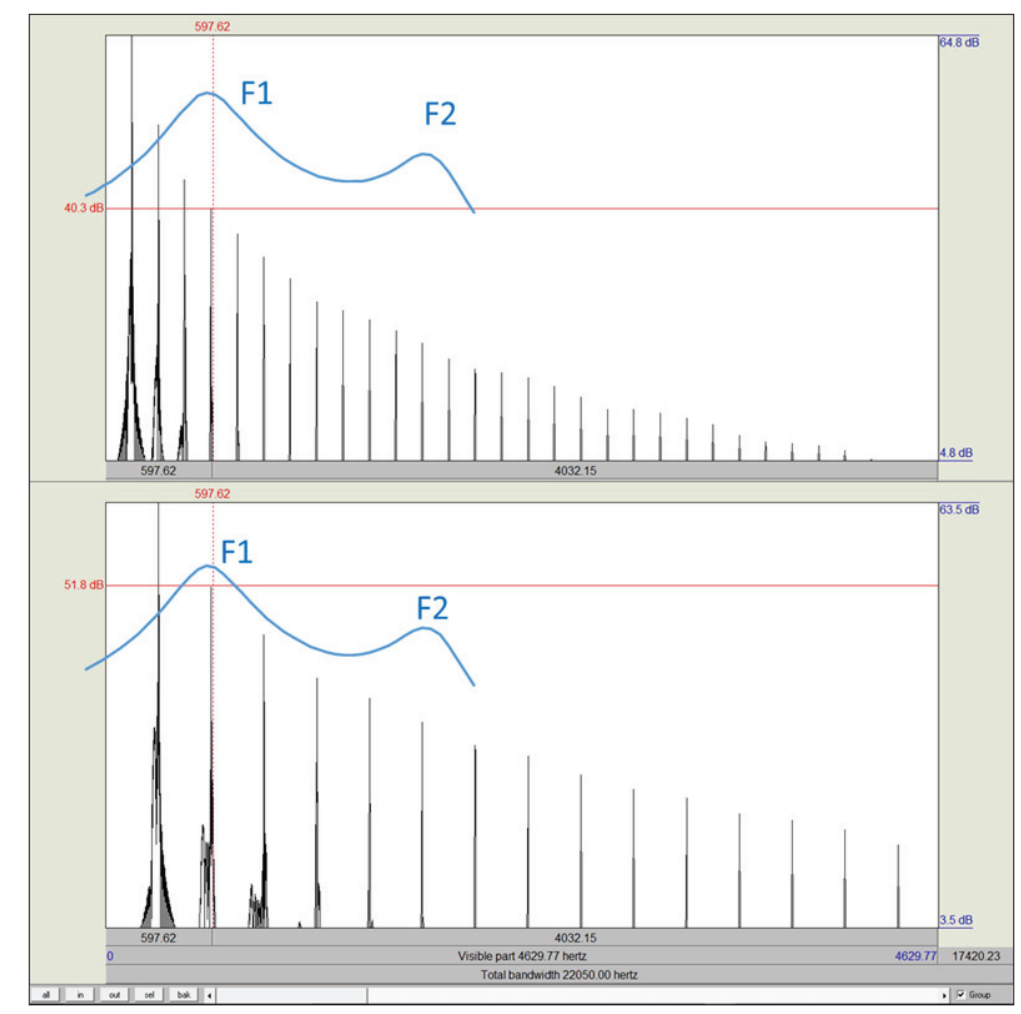

Joonis 5. Noodi d võimsusspekter (üleval) ja oktav kõrgema noodi $\mathrm{d}^{1}$ võimsusspekter (all). Võimsusspektritele asetatud kõver iseloomustab vokaaltrakti ülekandekarakteristikut kahe alumise formandi piirkonnas vokaali / a / laulmisel. Madalama noodi (d) puhul langeb esimese formandi sagedus F1 neljanda osaheli ligidale, oktav kõrgemal $\left(\mathrm{d}^{1}\right)$ on selleks aga palju tugevam teine osaheli (vt vertikaalse kursorijoone asukohta). 
Tabel 3. Faktorid, mis võisid mõjutada LH1-LF1 (põhitooni suhtelise tugevuse) väärtust.

\begin{tabular}{|c|c|c|c|}
\hline Faktor & $\begin{array}{l}\text { Mõju } f-f \\
\text { ülesandes }\end{array}$ & $\begin{array}{l}\text { Mõju } p-f \\
\text { ülesandes }\end{array}$ & $\begin{array}{l}\text { Mõju } f-p \\
\text { ülesandes }\end{array}$ \\
\hline $\begin{array}{l}\text { 1. Kui helikõrgus tõuseb, } \\
\text { kaldub LF1 väärtus } \\
\text { suurenema, sest see } \\
\text { osaheli, mis on F1-le } \\
\text { kõige ligemal, osutub } \\
\text { järjest madalamal } \\
\text { positsioonil olevaks. } \\
\text { Madalamad osahelid } \\
\text { hääleallika spektris on } \\
\text { aga reeglina tugevamad. }\end{array}$ & \multicolumn{3}{|c|}{$\begin{array}{l}\text { LH1-LF1 väärtus langeb } \\
\text { Selle faktori mõju suurus oleneb hääleallika spektri } \\
\text { kaldest (tüüpiliselt vahemikus }-12 \text { kuni }-6 \mathrm{~dB} / \text { oktavi } \\
\text { kohta). Võimalik on ka lokaalne ebaühtlus trendis, } \\
\text { sõltuvalt F1 kaugusest osahelist. }\end{array}$} \\
\hline $\begin{array}{l}\text { 2. Helikõrguse tõustes } \\
\text { liigub H1 lähemale } \\
\text { F1-le, mistõttu formandi } \\
\text { võimendav mõju LH1-le } \\
\text { kasvab. }\end{array}$ & \multicolumn{3}{|c|}{$\begin{array}{l}\text { LH1-LF1 suureneb veidi } \\
\text { Antud ülesannete puhul polnud selle faktori mõju } \\
\text { kunagi suurem kui umbes } 2-3 \mathrm{~dB} \text {, hinnangu alusel, mis } \\
\text { põhines pöördfiltreerimise käigus saadud vokaaltrakti } \\
\text { ülekandefunktsiooni analüüsil. }\end{array}$} \\
\hline $\begin{array}{l}\text { 3. Häälepaelte aluse } \\
\text { ôhurõhu tõstmine } \\
\text { muudab kõik osahelid } \\
\text { tugevamaks, kuid } \\
\text { kõrgemad osahelid } \\
\text { tugevnevad rohkem. }\end{array}$ & $\begin{array}{l}\text { LH1-LF1 võib } \\
\text { väheneda, } \\
\text { kui koos } \\
\text { helikõrgusega } \\
\text { tõuseb ka } \\
\text { häälepaelte alune } \\
\text { rõhk, sest LF1 } \\
\text { kasvab rohkem } \\
\text { kui LH1. }\end{array}$ & $\begin{array}{l}\text { LH1-LF1 } \\
\text { väheneb, sest } \\
\text { häälepaelte aluse } \\
\text { rõhu tõstmisel } \\
\text { kasvab LF1 } \\
\text { rohkem kui LH1. }\end{array}$ & $\begin{array}{l}\text { LH1-LF1 } \\
\text { kasvab, kuna } \\
\text { häälepaelte aluse } \\
\text { rõhu langetamisel } \\
\text { kahaneb LF1 } \\
\text { rohkem kui LH1. }\end{array}$ \\
\hline $\begin{array}{l}\text { 4. Formandi } \\
\text { häälestamise mõju: } \\
\text { LF1 on tugevam, kui } \\
\text { F1 paikneb osahelile } \\
\text { ligemal ja LF1 on } \\
\text { nõrgem, kui F1 jääb } \\
\text { kahe osaheli vahelise } \\
\text { ala keskkohta. }\end{array}$ & \multicolumn{3}{|c|}{ Võimalikud ebaühtlused LH1-LF1 graafiku kujus. } \\
\hline $\begin{array}{l}\text { 5. Glotaalse } \\
\text { aduktsiooni mõju: } \\
\text { tugevama aduktsiooni } \\
\text { puhul on põhitoon } \\
\text { (LH1) nõrgem. }\end{array}$ & $\begin{array}{l}\text { Idiosünkraatilised } \\
\text { strateegiad. }\end{array}$ & $\begin{array}{l}\text { Kuna CQ kaldub } \\
\text { tõusma, siis } \\
\text { LF1 kasvab } \\
\text { rohkem kui LH1 } \\
\text { ja LH1-LF1 } \\
\text { väärtus kaldub } \\
\text { langema. }\end{array}$ & $\begin{array}{l}\text { Kuna CQ kaldub } \\
\text { vähenema, siis } \\
\text { LF1 väheneb } \\
\text { rohkem kui } \\
\text { LH1, LH1-LF1 } \\
\text { väärtus kaldub } \\
\text { tõusma. }\end{array}$ \\
\hline $\begin{array}{l}\text { KÕIGI FAKTORITE } \\
\text { KESKMINE } \\
\text { SUMMMARNE MÕJU } \\
\text { KÄESOLEVAS TÖÖS }\end{array}$ & $\begin{array}{l}\text { LH1-LF1 } \\
\text { väärtus langes } \\
-4 \mathrm{~dB} / \text { oktavi } \\
\text { kohta. }\end{array}$ & $\begin{array}{l}\text { LH1-LF1 } \\
\text { väärtus langes } \\
-13 \mathrm{~dB} / \text { oktavi } \\
\text { kohta. }\end{array}$ & $\begin{array}{l}\text { LH1-LF1 } \\
\text { väärtus tõusis } \\
\text { veidi }(2 \mathrm{~dB} / \\
\text { oktavi kohta). }\end{array}$ \\
\hline
\end{tabular}

Märkus: Paksus kirjas esitatud faktorid sõltuvad laulja vokaaltehnikast. 
Faktori 2 sisu sarnaneb eelmisele ning viitab sellele, et ka LH1 sõltub lauldava noodi kõrgusest. Meie ülesannete puhul - mida kõrgem oli lauldav noot, seda ligemal paiknes põhitooni komponent F1-le ja seda suurem oli seetõttu esimese formandi tugevdav mõju põhitooni komponendile. See faktor ei mõjutanud reaalselt LH1e väärtust siiski rohkem kui 2-3 dB. (Hindasime seda vokaaltrakti ülekandefunktsioonide põhjal, mille genereeris pöördfiltreerimise käigus operaatori valitud formantsageduste alusel programm Sopran 1.0.10.) Kuigi kaks esimest faktorit tõstsid hääle kõrgenedes nii LF1 kui ka LH1 väärtusi, oli tõus suurem LF1 puhul ja summaarseks mõjuks kujunes seetõttu LH1-LF1 kahanemine.

Ülejäänud kolm faktorit tabelis 3 sõltuvad laulja vokaaltehnikast. Vokalistid saavad reguleerida häälepaelte aluse õhurõhu suurust (faktor 3), formantsagedusi (faktor 4) ja glotaalse aduktsiooni tugevust (faktor 5).

Häälepaelte aluse õhurõhu suurendamine (faktor 3) suurendab kõikide osahelide amplituudi, kuid kõrgemad osahelid tugevnevad seejuures suuremal määral kui madalamad (Sundberg 1987). On loogiline oletada, et faktori nr 3 mõju hääle spektrikomponentide tugevusbalansile on eriti suur nende kahe ülesande puhul, kus laulja pidi teadlikult muutma hääle dünaamikat (kuna hääle tugevust reguleeritakse peamiselt häälepaeltealuse rõhu abil). Vastav mõju võib esineda aga ka $f$ - $f$ ülesande täitmisel, sest lauljad kalduvad häälepealte alust õhurõhku suurendama hääle kõrgenedes ka siis, kui otseselt ei kavatsetagi laulda valjemini (Björkner 2008).

Lauljad saavad lauldava hääliku kategooriat säilitades teatud määral reguleerida ka formantsagedusi (faktor 4), sest taju kategoriaalsuse tõttu kuuleme ikka sedasama vokaali, kui esimese ja teise formantsageduse varieerumine ei ületa vastava vokaalikategooria tinglikke piire (Sundberg 2013). LF1-LH1 väärtuse kujunemisel on määravaim $\mathrm{F} 1$, mis sõltub peamiselt suu avatuse määrast - F1 tõuseb, kui suu on rohkem lahti (Sundberg 1987). F1 väärtuse mõjumehhanism LF1-LH1 väärtuse kujunemisele on põhimõttelisel seesama, mida kirjeldavad faktorid 1 ja 2 . Seetõttu võib faktori 4 puhul väita, et ühtaegu on see laulja vokaaltehnikast sõltumatu ja ka sellest sõltuv, sest F1 ja osaheli vahelist häälestumist mõjutab nii suu avatus ja sellega seotud F1 (lauljast sõltuv aspekt) kui ka hääle kõrgus (lauljast sõltumatu aspekt, kuna tõusva helirea laulmine oli meie ülesannetes lauljale ette kirjutatud).

Viienda faktorina saab laulja reguleerida glotaalse aduktsiooni määra, mis väljendub CQ ja QxEGG väärtustes. See mõjutab peamiselt alghääle spektri kahe esimese osaheli tugevusvahekorda (LH1-LH2), mis kaldub vähenema (st põhitoon muutub nõrgemaks), kui aduktsioon on tugevam (Holmberg et al. 1995). Alghääle spektris nõrgema põhitooni puhul on siis eeldatavasti ka LH1LF1 väärtus madalam. 
Tabel 4. Faktorid, mis võisid mõjutada LF3-LF1 (lauljaformandi suhtelise tugevuse) väärtust.

\begin{tabular}{|c|c|c|c|}
\hline Faktor & $\begin{array}{l}\text { Mõju } f-f \\
\text { ülesandes }\end{array}$ & $\begin{array}{l}\text { Mõju } p-f \\
\text { ülesandes }\end{array}$ & $\begin{array}{l}\text { Mõju } f-p \\
\text { ülesandes }\end{array}$ \\
\hline $\begin{array}{l}\text { 1. Helikõrguse tõustes } \\
\text { kalduvad suurenema nii } \\
\text { LF1 kui LF3 väärtused, } \\
\text { sest see osaheli, mis on } \\
\text { vastavalt kõige lähemal } \\
\text { kas esimesele formandi- } \\
\text { le või lauljaformandile, } \\
\text { hakkab vahetuma ja sel- } \\
\text { le järjekorranumber osa- } \\
\text { helide reas muutub } \\
\text { järjest väiksemaks. Mida } \\
\text { madalam on alghää- } \\
\text { le osaheli, seda tugevam } \\
\text { ta aga on. }\end{array}$ & \multicolumn{3}{|c|}{$\begin{array}{l}\text { Mõju LF3-LF1 väärtusele puudub või on väike, } \\
\text { sest LF3 ja LF1 väärtused suurenevad eeldatavasti } \\
\text { ühtemoodi. }\end{array}$} \\
\hline $\begin{array}{l}\text { 2. Häälepaeltealuse } \\
\text { õhurõhu tõstmine } \\
\text { tugevdab kõiki } \\
\text { osahelisid, kuid } \\
\text { tugevnemine on } \\
\text { suurem kõrgemate } \\
\text { osahelide puhul. }\end{array}$ & $\begin{array}{l}\text { LF3-LF1 võib } \\
\text { veidi tõusta, kui } \\
\text { laulja suurendab } \\
\text { häälepaeltealust } \\
\text { rõhku. }\end{array}$ & $\begin{array}{l}\text { LF3-LF1 tõuseb, } \\
\text { sest LF3 väärtus } \\
\text { tõuseb õhurõhu } \\
\text { suurendamisel } \\
\text { crescendot tehes } \\
\text { rohkem kui LF1 } \\
\text { väärtus. }\end{array}$ & $\begin{array}{l}\text { LF3-LF1 langeb, } \\
\text { sest LF3 väärtus } \\
\text { langeb õhurõhu } \\
\text { vähendamisel } \\
\text { diminuendot } \\
\text { tehes rohkem kui } \\
\text { LF1 väärtus. }\end{array}$ \\
\hline $\begin{array}{l}\text { 3. Lauljaformandi } \\
\text { tehnika kasutamine } \\
\text { (kõrgemate formantide } \\
\text { klasterdamine). }\end{array}$ & \multicolumn{3}{|c|}{$\begin{array}{l}\text { Mõju puudub, kui lauljaformandi tehnika kasutamine on } \\
\text { järjekindel. Vastasel juhul LF3-LF1 väärtus tõuseb, kui } \\
\text { lauljaformanti kasutatakse. }\end{array}$} \\
\hline $\begin{array}{l}\text { 4. Formandi } \\
\text { häälestamise efekt: } \\
\text { LF1 tõuseb, kui F1 } \\
\text { ja osaheli paiknevad } \\
\text { üksteisele ligemal. } \\
\end{array}$ & \multicolumn{3}{|c|}{$\begin{array}{l}\text { LF3-LF1 muutmise graafikus sõltuvalt noodikõrgusest } \\
\text { võivad tekkida ebaregulaarsused. }\end{array}$} \\
\hline $\begin{array}{l}\text { 5. Glotaalse } \\
\text { aduktsiooni tugevus: } \\
\text { tugevama aduktsiooni } \\
\text { korral muutuvad } \\
\text { kõrgemad osahelid } \\
\text { proportsionaalselt } \\
\text { tugevamaks. }\end{array}$ & $\begin{array}{l}\text { Mõju on } \\
\text { individuaalne. }\end{array}$ & $\begin{array}{l}\text { LF3-LF1 kaldub } \\
\text { suurenema, } \\
\text { sest crescendo } \\
\text { puhul kaldub } \\
\text { aduktsioon } \\
\text { tugevnema. }\end{array}$ & $\begin{array}{l}\text { LF3-LF1 kaldub } \\
\text { vähenema, sest } \\
\text { diminuendo } \\
\text { puhul kaldub } \\
\text { aduktsioon } \\
\text { nõrgenema. }\end{array}$ \\
\hline $\begin{array}{l}\text { 6. Häälepilu läbivate } \\
\text { õhuimpulsside vildakuse } \\
\text { vähenemine ja sellest } \\
\text { tulenev kõrgemate } \\
\text { osahelide nõrgenemine } \\
\text { helikõrguse tõustes. }\end{array}$ & \multicolumn{3}{|c|}{ LF3-LF1 kaldub kõrgetel nootidel kahanema. } \\
\hline $\begin{array}{l}\text { KÕIGI FAKTORITE } \\
\text { KESKMINE } \\
\text { SUMMAARNE MÖJU } \\
\text { KÄESOLEVAS TÖÖS }\end{array}$ & $\begin{array}{l}\text { Väike LF3- } \\
\text { LF1 langus } \\
\text { päris kõrgetel } \\
\text { nootidel. }\end{array}$ & $\begin{array}{l}\text { LF3-LF1 } \\
\text { kaldub tõusma, } \\
\text { kuid langeb } \\
\text { päris kõrgetel } \\
\text { nootidel. }\end{array}$ & $\begin{array}{l}\text { LF3-LF1 kaldub } \\
\text { langema. }\end{array}$ \\
\hline
\end{tabular}

Märkus: Paksus kirjas esitatud faktorid sõltuvad laulja vokaaltehnikast. 
Faktorid, mis võisid põhjustada muutusi LF3-LF1 väärtuses on toodud tabelis 4 . Faktor 1 selles tabelis on sisult seesama, mis faktor 1 tabelis 3 , erinevus on vaid selles, et siin on hõlmatud selle mõju ka LF3 väärtusele. Kuna selle faktori mõju nii LF1-le kui ka LF3-le helikõrguse muutumisel on alghääle spektri ühesugusena püsiva kalde korral samasugune (ja samasuguse suunaga), siis mõju LF3-LF1 väärtusele puudub (või on väike). Faktor 2 viitab asjaolule, et häälepaeltealuse rõhu suurenemisel tugevnevad kõik spektrikomponendid, kuid tugevnemine on suurem kõrgemate osahelide puhul. Seetõttu võime eeldada, et rõhu kasvades suureneb LF3 rohkem kui LF1 ja lauljaformant muutub resultaadina prominentsemaks. Faktor 3 (lauljaformandi kasutamine) tõstab LF3. Kui laulja kasutab lauljaformandi tehnikat järjekindlalt, siis selle mõju hääle spektrile on eeldatavasti terve ülesande vältel ühesugune. Faktor 4 viitab sellele, et spektri mingi osaheli tugevneb, kui laulja häälestab formantsageduse paremini kokkulangevaks selle osaheli sagedusega (või tekib parem kokkulangevus puht-akustilistel põhjustel helikõrguse muutudes). Faktor 5 räägib sellest, et pressitum fonatsioon (glotaalse aduktsiooni tugevnemine) kahandab hääle spektri kallet (st kõrgemad osahelid muutuvad tugevamaks). Faktor 6 (kõriimpulsside kaldususe vähenemine kõrgete nootide puhul) ei olene tõenäoliselt samuti laulja vokaaltehnikast, kuna selle põhjustab vokaaltrakti akustilise impedantsi muutumine, kui H1 ja F1 vaheline kaugus muutub väiksemaks. Meie ülesannetes kohustusliku helistiku ja tõusva heliredeli puhul vähenes see vahekaugus vältimatult.

\section{Tulemused ja analüüs II: Individuaalsed erinevused}

Üldised tendentsid, kuidas muutusid ülesannetes tugevusbalansid hääle spektri strateegiliste piirkondade vahel, olid sarnased enamiku lauljate puhul. Siiski võis märgata mõningaid individuaalseid erinevusi. Järgnevalt analüüsime ja võrdleme nelja selles osas rohkem huvi pakkunud laulja (A, E, H ja K) sooritusi eraldi. Detailsemaks analüüsiks välja valitud lauljate puhul avaldus iga konkreetne strateegia kõige selgemini ja järjekindlamalt. Kõigi lauljate individuaalsete tulemuste esitamine poleks siin otstarbekas teadusartikli formaadi piiratud mahu tõttu. Kõige rohkem erinesid lauljad selles, (1) kuidas nad laulsid $f-p$ ülesandes kõrgeid noote ning (2) kuidas tekitasid kõrgetel nootidel mulje piano ja forte dünaamika erinevusest ( $p-f$ ja $f-p$ ülesannetes).

Joonisel 6 on toodud lauljate K, A, E ja H individuaalsed LH1, LF1 ja LF3 muutumise graafikud sõltuvalt lauldava noodi kõrgusest kõigi kolme ülesande puhul. Kõik joonistel kujutatud helitaseme väärtused detsibellides on normeeritud kõige kõrgema spektraalse parameetri väärtuse suhtes, mis 


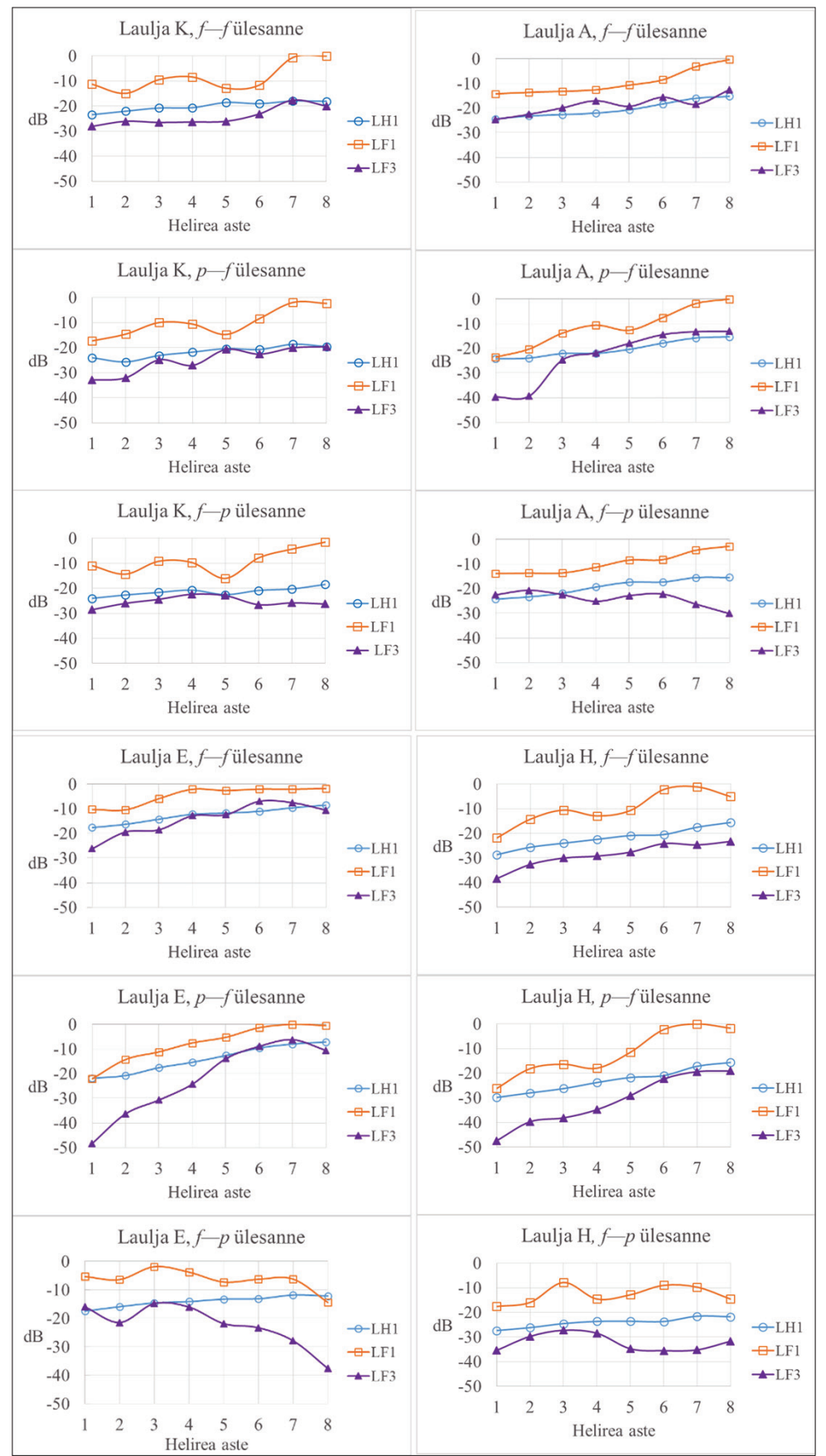

Joonis 6. Lauljate K, A, E ja H individuaalsete LH1, LF1 ja LF3 väärtuste muutumine sõltuvalt helirea astmekõrgusest. Graafikud on normeeritud konkreetse laulja maksimaalse LF1 väärtuse suhtes. Relatiivne $0 \mathrm{~dB}$ joonisel vastab ligikaudu järgmistele absoluutsetele helirõhu väärtustele mõõdetuna $30 \mathrm{~cm}$ kauguselt: laulja K puhul $112 \mathrm{~dB}$, A puhul $107 \mathrm{~dB}, \mathrm{E}$ puhul $103 d B$ ja H puhul 106 dB. 
esines konkreetse laulja puhul kõigi kolme spektraalse parameetri, ülesande variandi ja kaheksa astmekõrguse lõikes. Üldjuhul oli selleks LF1 väärtus $p-f$ ülesande kaheksanda heliredeli astme laulmisel. Seega on joonistel esitatud detsibelliväärtuste abil võimalik omavahel võrrelda erinevate spektripiirkondade tugevusvahekordi ja jälgida, kuidas muutub vastava spektriosa tugevus sõltuvalt hääle kõrgusest. Absoluutskaalal aitab vastavaid väärtusi võrrelda joonise allkirja juurde lisatud informatsioon $0 \mathrm{~dB}$ väärtuse paiknemise kohta skaalal iga konkreetse laulja puhul.

Kõigi nelja laulja puhul muutus kõige kitsamates piirides ja kõige ühtlasemalt LH1 (põhitooni tugevus). LH1 muutumise vahemik oli kõige väiksem (vaid $6 \mathrm{~dB}$ ) lauljate $\mathrm{H}$ ja K puhul ning kõige suurem (14 dB) laulja E puhul. Tähelepanu väärib, et kõigi nelja laulja puhul muutus LH1 helirea kõrgenedes alati tugevamaks, seda isegi siis, kui ülesanne oli laulda diminuendos.

Kõige laiemas vahemikus varieerus lauljate A, E ja H puhul LF3 väärtus, kuid laulja K puhul LF1 väärtus. Ka lauljate A, E ja H puhul oli LF1 varieerumise ulatus siiski selgelt laiem võrreldes LH1 muutumise ulatusega.

Laulja K puhul on LF1 graafikud peaaegu ühesugused kõigi kolme dünaamikaülesande laulmisel: hääle kõrgenedes LF1 väärtus tõusis alati ja isegi siis, kui ülesandeks oli laulda diminuendos (joonis 6, vasakul ülal). Suurim oli erinevus helirea esimese astme laulmisel, kus fortes oli LF1 6 dB tugevam võrreldes pianoga. (Meenutagem, et LF1, kui enamasti spektri kõige tugevama komponendi tase iseloomustab suhteliselt hästi ka hääle kui terviku helirõhu taset. LF1 seost hääletugevusega kinnitas ka SPL mõõtmine lisamikrofoniga.) Olgugi, et laulja K puhul oli tendentsiks LF1 tugevnemine koos nootide kõrgenemisega, esines tema soorituses alati viienda helirea astme juures $(f-f$ ning $f-p$ ülesannetes ka helirea teise astme juures) väike lokaalne LF1 nõrgenemine. Languse põhjustas arvatavasti see, et viienda astme laulmisel jäi F1 üsna täpselt teise ja kolmanda osaheli vahele (mistõttu F1 ei suutnud eriti võimendada kumbagi neist) ja teise astmekõrguse laulmisel jäi F1 kolmanda ja neljanda osaheli vahele.

Kui nii LH1 kui LF1 väärtused kõrgete nootide puhul ei sõltunud just palju sellest, kas laulja K laulis $p \_f$ või $f-p$ ülesandevarianti, siis rohkem sõltus dünaamikast LF3 (lauljaformandi taseme) väärtus, mis oli heliredeli kaheksanda astme laulmisel pianos $7 \mathrm{~dB}$ madalam võrreldes fortega (vt ka joonis 7, paneelid vasakul ülal). Kuna LF1 jäi suhteliselt muutumatuks, aga LF3 vähenes, siis vähenes kõrgete nootide laulmisel pianos ka LF3-LF1.

Järgnevalt analüüsime, milliseid vokaaltehnilisi võtteid võis laulja $K$ kasutada, et tekitada eelpoolkirjeldatud erinevus forte ja piano vahel helirea kaheksanda astmekõrguse $\left(d^{1}\right)$ laulmisel. Täpsemat informatsiooni kahe madalama formantsageduse ( $\mathrm{F} 1 \mathrm{ja} \mathrm{F} 2)$ paiknemise kohta saime pöördfiltreerimise 


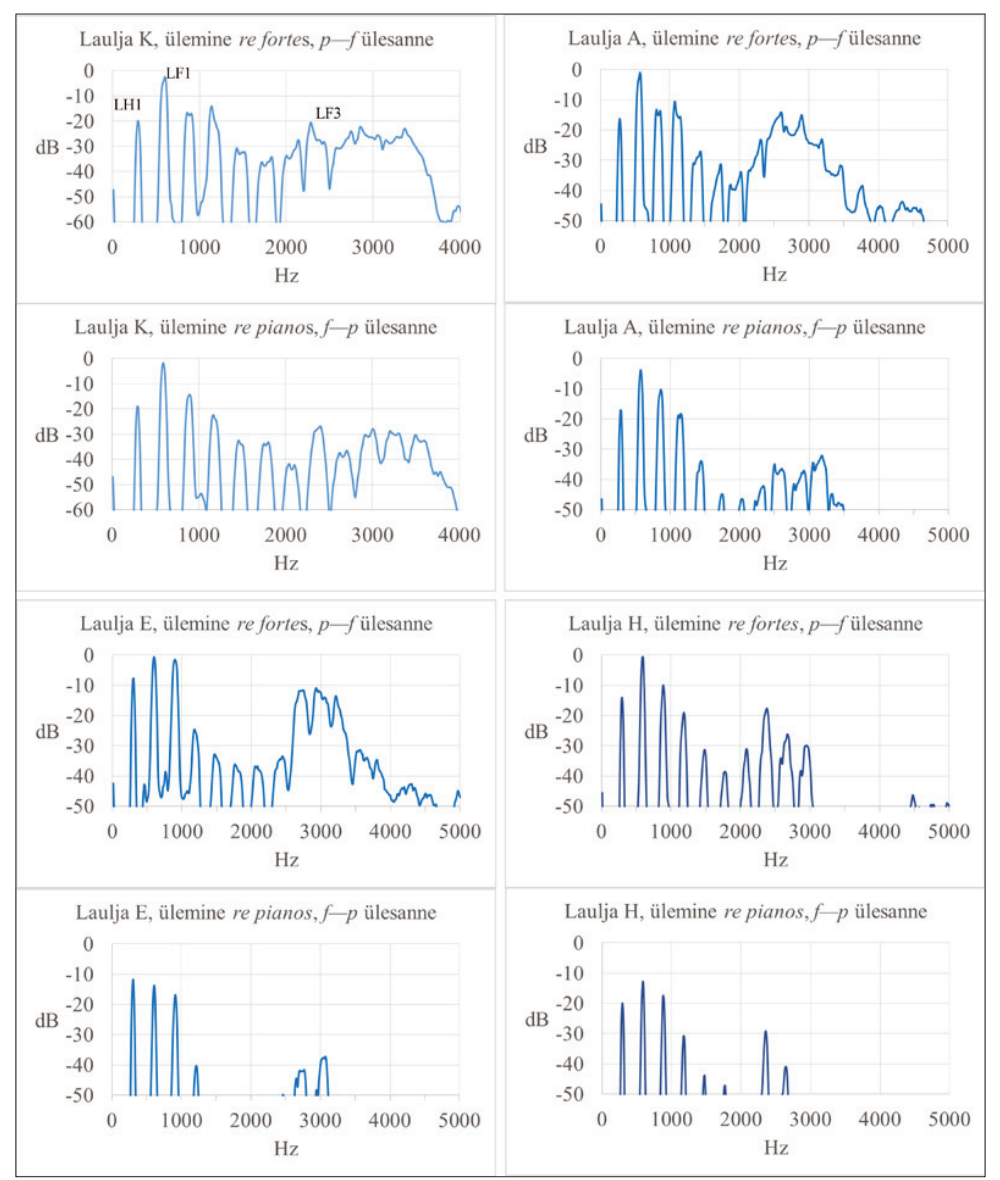

Joonis 7. Lauljate K, A, E ja H hääle võimsusspektrid kaheksanda astmekõrguse laulmisel fortes ja pianos. Relatiivne $0 \mathrm{~dB}$ joonisel vastab ligikaudu järgmistele absoluutsetele helirõhu väärtustele mõõdetuna $30 \mathrm{~cm}$ kauguselt: laulja K puhul $112 \mathrm{~dB}$, A puhul $107 \mathrm{~dB}, \mathrm{E}$ puhul 103 dB ja H puhul 106 dB.

protseduuri läbi viies, kui optimeerisime vokaaltrakti ülekandefunktsiooni kuju. Selle põhjal olid fortes lauldes nii F1 kui ka F2 veidi kõrgemad võrreldes pianoga (fortes $\mathrm{F} 1=612 \mathrm{~Hz}$ ja F2 $=1068 \mathrm{~Hz}$ ning pianos $\mathrm{F} 1=587 \mathrm{~Hz}$ ja F2 = 1034 $\mathrm{Hz}$ ). Formantsageduste muutumise põhjal võime oletada, et vaikselt lauldes oli laulja suu veidi vähem avatud ja keele positsioon rohkem taga võrreldes fortega (formantsageduste ja artikuleerimisorganite asendite seose kohta vt Sundberg 1987). Kõige lähemal F1-le paiknes teine osaheli, mille sagedus $d^{1}$ puhul oli $\mathrm{H} 2=587 \mathrm{~Hz}$.

Seitse detsibelli madalam LF3 ja peaaegu muutumatu LF1 pianos võrrelduna fortega (noodi $d^{1}$ laulmisel) võis seetõttu tekkida järgmiste tegurite koosmõju 
tõttu: (1) F2 madaldumine $1068 \mathrm{~Hz}$-st fortes kuni $1034 \mathrm{~Hz}$-ni pianos muutis teise formandi ja lauljaformandi vahelise kauguse suuremaks ja põhjustas seega LF3 alanemise (kuna nende teineteist tugevdav mõju vähenes), (2) pianos langes F1 täpsemini kokku H2 sagedusega (võrreldes fortega), mistõttu LF1 tugevnes, (3) piano puhul võis laulja tõenäoliselt vähendada häälepaeltealust rõhku, mis alandas nii LF1 väärtust (vastukaaluks eelmises punktis mainitud LF1 tugevnemisele), kuid veel rohkem LF3 väärtust, (4) laulja kasutas lauljaformandi tehnikat $d^{1}$ laulmisel pianos tõenäoliselt vähem efektiivselt, sest lauljaformandi piirkonna spektripiigid asetsevad piano korral veidi rohkem hajali (vt joonis 7, paneelid vasakul ülal).

Erinevused hääle spektris piano ja forte puhul tõenäoliselt ei olenenud muutustest laulja K häälekurdude aduktsioonitugevuses, sest seda iseloomustavate parameetrite CQ ja QxEGG väärtused helirea kaheksanda astmekõrguse laulmisel praktiliselt ei olenenud ülesande dünaamikaversioonist, jäädes vastavalt vahemikku 47-48\% CQ puhul ja 62-63\% QxEGG puhul. Seega võib kokkuvõttes väita, et laulja K ei muutnud kõrgete nootide laulmisel pianos (võrreldes fortega) mitte niivõrd hääle SPLi, vaid tämbrit, mis väljendus lauljaformandi prominentsuse vähenemises.

Ka laulja A LF1 graafikud tõusevad üsna ühtemoodi helirea kõrgenedes kõigi kolme ülesande puhul (joonis 6, paneelid ülal paremal). Vaid kahe kõige alumise astmekõrguse laulmisel oli LF1 väärtus piano puhul ligikaudu $10 \mathrm{~dB}$ nõrgem kui fortes. Sarnaselt laulja K produktsioonile muutus dünaamikaga kõige rohkem LF3 väärtus, mis oli nii helirea esimese kui kaheksanda astme laulmisel pianos $17 \mathrm{~dB}$ nõrgem võrreldes samade nootide laulmisega fortes. Ka selle laulja puhul võis LF3 väärtuse vähenemisele pianos viia taganemine lauljaformandi tehnikast. Kui fortes laulmisel oli lauljaformandi piirkonnas (ligikaudu 2,5-3 kHz) paikneva spektritõusu ribalaius umbes $400 \mathrm{~Hz}$, siis pianos laulmisel oli vastav ribalaius umbes kaks korda suurem, viidates kõrgemate formantide klasterdumise (ja seega lauljaformandi prominentsuse) vähenemisele (vt joonis 7, paneelid ülal paremal). Tüüpiline vokaaltehnika lauljaformandi tekitamiseks on kõri madaldamine, mis samal ajal viib madalamaks ka kõik formantsagedused (Sundberg 1987). Pöördfiltreerimisel mõõdetud F1 madaldumine $638 \mathrm{~Hz}$-st piano puhul kuni $607 \mathrm{~Hz}$-ni fortes on kooskõlas meie hüpoteesiga lauljaformandi tehnika muutumisest. F2 puhul toimus aga hoopis tõus 1003 Hz-st kuni 1037 Hz-ni, mis räägib sellele hüpoteesile vastu. Kuna F1 ja F2 olenevad väga palju suu- ja keeleasendi valikust häälikute artikuleerimisel, ei pruukinud eelpoolkirjeldatud muutused siiski olla seotud ainult laulja kõriasendiga. LF3 nõrgenemisel aga ka LH1 tugevnemisel pianos võis rolli mängida ka glotaalse aduktsiooni nõrgenemine, sest CQ väärtus forte puhul oli 48\%, kuid see alanes piano puhul 37\%-ni (vastavad QxEGG väärtused olid $64 \%$ ja $58 \%$ ). 
Seega võime ka laulja A puhul väita, et sarnaselt K-le muutis A kõrgete nootide laulmisel pianos eelkõige hääle tämbrit, mille sisuks oli lauljaformandi prominentsuse vähendamine. Otsene helirõhutase kõrgetel nootidel muutus suhteliselt vähe. Madalatel nootidel eristasid piano ja forte dünaamikat siiski nii erinevus SPL kui ka LF3-LF1 väärtustes.

Laulja E puhul sõltusid nii LF1 kui LF3 ülesannetes nõutud dünaamikast eelmiste lauljatega võrreldes oluliselt suuremal määral (joonis 6, paneelid vasakul all). $f-p$ ülesande jooksul LF1 langes, mis on kooskõlas intuitiivselt eeldatavaga, et vaiksemalt laulmisel SPL väheneb (kuid mis oli vastupidine lauljate Kja A sooritusele). $p$-fülesande jooksul LF1 tõusis sarnaselt lauljatele $\mathrm{K}$ ja A (mis on samuti kooskõlas intuitiivselt eeldatavaga). Helirea esimese astme laulmisel oli LF1 pianos 16 dB nõrgem võrreldes fortega. Kaheksanda helirea astme juures oli vastav erinevus 12 dB. LF3 väärtus kaheksanda helirea astme laulmisel pianos oli aga $28 \mathrm{~dB}$ nõrgem kui fortes laulmisel, esimese astme puhul oli vastav erinevus LF3 tasemetes lausa $32 \mathrm{~dB}$.

Laulja E eristus teistest ka selle poolest, et ta kasutas piano puhul äärmiselt madalat häälepaelte aduktsiooni: kaheksanda astmekõrguse laulmisel pianos mõõtsime $\mathrm{CQ}$ väärtuseks 5,5\% (QxEGG = 30\%). (Madala aduktsiooni korral on aga nii CQ kui QxEGG mõõtmine ebausaldusväärsem ja seetõttu ei pruukinud tegelikult täielikku häälepaelte sulgumist võnketsüklis toimudagi.) Forte puhul olid CQ ja QxEGG väärtused küll kõrgemad, vastavalt $30 \%$ ja $42 \%$, aga võrreldes lauljate $\mathrm{K}$ ja A produktsiooniga siiski selgelt madalamad. Arvatavasti peamiselt madala glotaalse aduktsiooni tõttu oli laulja E puhul põhitooni komponent spektris tugev - kaheksanda astmekõrguse laulmisel pianos osutus LH1 isegi paari detsibelli võrra tugevamaks kui LF1.

Võimsusspektrite põhjal (joonis 7, paneelid vasakul all) võib väita, et vokalist E kasutas järjekindlalt lauljaformandi tehnikat ka piano puhul, sest vastava piirkonna spektritõusu ribalaius võrreldes fortega pigem kitsenes. Kokkuvõttes võime laulja E puhul väita, et laulja muutis dünaamikaülesannete täitmise käigus hääle omadusi laiades piirides (või lasi neil reflektoorselt muutuda). Piano laulmisel kõrgetel nootidel muutus hääle SPL oluliselt madalamaks ja hääletämber vähem kandvaks ja tuhmimaks selles aspektis, mida määrab lauljaformandi suhteline tugevus. Vokaaltehniliselt vähendas laulja selleks oluliselt glotaalset aduktsiooni ja tõenäoliselt ka häälepaeltealuse rõhu suurust. Võime oletada, et ooperilavadel ei ole sedavõrd suur hääleomaduste varieeruvus tüüpiline, sest laulja E professionaalne kogemus võrreldes lauljate K ja A-ga oli oluliselt tagasihoidlikum.

Ka laulja H puhul oli LF1 väärtus kõrgetel nootidel pianos laulmisel kuni $15 \mathrm{~dB}$ madalam võrreldes fortega (joonis 6, paneelid paremal all). Helirea kõige madalamate nootide puhul polnud erinevus siiski suurem, kui umbes $7 \mathrm{~dB}$. 
Selle laulja sooritusele on iseloomulik veel LF1 alanemine $2-5 \mathrm{~dB}$ võrra helirea kaheksanda astme juures võrreldes sellele eelneva seitsmenda astmega. See toimus ka $p \_f$ ülesande laulmisel, ehkki loogiline oleks eeldada helitaseme tõusu jätkumist helirea lõpuni. Analoogne LF1 väärtuse lokaalne vähenemine mõne detsibelli võrra toimus ka helirea neljanda astme laulmisel. Selle põhjuseks võis olla osaheli ja esimese formandi omavahelise häälestuse lokaalne halvenemine helikõrguse muutumisel.

Laulja H LF3 graafik tõuseb ootuspäraselt $p-f$ ülesande laulmisel koos LF1 graafiku tõusuga. LF3-LF1 väärtus (lauljaformandi prominentsus) jääb seejuures suhteliselt püsivaks. Teistest lauljatest erinev on LF3 graafiku kulg aga $f-p$ ülesande puhul. Helirea ülemiste nootide juures see mitte ei lange, vaid isegi tõuseb mõned detsibellid. Selle tulemusena muutub lauljaformant kaheksanda astmekõrguse laulmisel eelnenud nootidega võrreldes isegi veidi prominentsemaks, hoolimata heli üldise SPL langusest.

Püüame ka siin teha oletusi laulja H vokaaltehniliste võtete kohta. Pöördfiltreerimisel saadud informatsiooni põhjal olid pianos lauldud kaheksanda helirea astme puhul esimese ja teise formandi sagedused vastavalt $\mathrm{F} 1=520 \mathrm{~Hz}$ ja F2 = $950 \mathrm{~Hz}$. See tähendab, et F1 jäi teise osaheli sagedusest ( $\mathrm{H} 2=587 \mathrm{~Hz}$ ) küllaltki kaugele, mistõttu formandi võimendav mõju osahelile osutus väikseks (ja sellega seotud üldine SPL tase jäi madalaks). Forte puhul oli esimese formandi sagedus kõrgem $(\mathrm{F} 1=554 \mathrm{~Hz})$ ja lähemal teisele osahelile $(\mathrm{H} 2=587 \mathrm{~Hz})$, mis aitas kaasa LF1 tugevnemisele. Seda näitavad ka vastavate nootidele võimsusspektrid (joonis 7, paneelid all paremal), kus forte puhul on F1-le vastav piik naaberpiikidega võrreldes prominentsemalt välja ulatuv. F2 sagedus fortes laulmisel võrreldes pianoga aga ei muutunud.

Lauljaformandile vastav tugevam spektriala muutus pianos laulmisel võrreldes fortega kitsamaks, mistõttu oletame, et lauljaformandi võime tugevdada sellesse piirkonda langevaid osahelisid pigem paranes. (See on vastupidine lauljate K ja A sooritusele, kelle puhul muutus lauljaformant pianos laiemaks ja vähem efektiivseks.) On võimalik, et LF1 madaldumise ja LF3 tõusu kombinatsiooni saavutamiseks kaheksanda astme laulmisel pianos võis laulja sellel noodikõrgusel paradoksaalselt veidi isegi suurendada häälepaeltealust õhurõhku (mille mõju on LF3 tugevdav) samal ajal hoides F1 möödahäälestatuna H2-st (mis langetas LF1 ja seega madaldas ka heli kui terviku SPL-i).

Seega võib laulja H puhul väita, et strateegia, mida võiks seostada hääle kõlaühtluse parandamisega, näis siin seisnevat lauljaformandi suhtelise tugevuse säilitamises kõrgemate formantide efektiivsema klasterdamise abil, kui tuli laulda pianos. Piano ja forte vahelise erinevuse tekitas laulja SPL varieerimise abil, mille üheks hoovaks oli esimese formandi sageduse madaldamine ja 
seeläbi F1 ning H2 vahelise distantsi suurendamine piano puhul. See alandas LF1 väärtust ja seega ka hääle kui terviku helitaset, aga samuti aitas hoida stabiilsemana lauljaformandi prominentsust väljendavat LF3-LF1 väärtust.

\section{Arutelu II: Üldised küsimused}

Käesoleva töö tulemused näitavad, et dünaamika ja helikõrguse varieerimisega seotud vokaalsete ülesannete täitmisel tekivad ka klassikaliselt treenitud professionaalsetel lauljatel muutused hääle spektri strateegiliste piirkondade tugevusvahekordades ehk hääle tämbris. Osa sellistest muutustest tekib puht-akustilistel põhjustel, mis pole seotud laulja vokaaltehnikaga. Lauljate käsutuses on küll erinevaid võimalusi, et parandada muljet häälekõla ühtlusest, kuid nad ei pruugi neid alati kasutada.

Kirjanduses on seni peamiselt analüüsitud olukordi, kus eesmärgiks on hääle kandvuse suurendamine. Sel juhul püüavad klassikaliselt treenitud lauljad väidetavalt vältida olukorda, kus F1 jääb H1-st madalamaks, ja modifitseerivad selleks kõnehääle vokaali (nt lauldes suud rohkem avades, et tõsta F1 sagedust, Sundberg 2013). Seni pole aga meile teadaolevalt uuritud strateegiaid, mida kasutavad lauljad, kui nad peavad laulma vaikselt.

Meie uurimuses oli lauljate $\mathrm{K}$ ja A strateegiaks kõrgete nootide laulmisel pianos lauljaformandi taseme alandamine, samal ajal hääle SPL taset kõrgel hoides. Tõenäoliselt oleks mõlemad lauljad olnud vokaaltehniliselt võimelised produtseerima häält ka SPLi kõrgetel nootidel alandades. Arvatavasti hoidusid nad sellest teadlikult, tahtes säilitada ooperižanrile omast laulmismaneeri. Nad püüdsid laulda tõenäoliselt nii, nagu neid oli õpetatud, mis vastas nende hääleliigi esitustraditsioonidele ja mida neil paluti ka teha eksperimendiks instrueerimisel.

Käsitlesime selles töös vaid mõnda hääleaspekti, mis võiksid olla olulised mulje tekitamisel ühtlaselt kõlavast häälest. Tähtsaks võivad osutuda aga ka veel mõned muud hääleomadused. Nii näiteks võib lauljaformandi suhtelise tugevuse või helirõhu taseme püsivana hoidmise kõrval olla oluline, et vastavate parameetrite muutumine erinevate vokaalsete ülesannete täitmisel toimuks sujuvalt, ilma järskude või juhuslike muutusteta. Sõnadega laulmisel vahetuvad häälikud kogu aeg. Ühtlasena tajutava hääle puhul võib olla oluline, et see tämbriaspekt häälikust, mis on seotud isiku hääletämbri individuaalsusega (ja mis oleneb eelkõige kõrgematest formantidest), jääks hääliku vahetumisel võimalikult samasuguseks. Ka sama vokaalikategooria piires modifitseerivad lauljad nn üleminekunootide piirkonnas sageli vokaali kvaliteeti nii kõlalistel 
eesmärkidel kui ka hääle kandvuse parandamiseks (Appelman 1967). Ka siin võib olla klassikalise laulukooli hääleesteetika seisukohalt oluline, kuidas täpselt vastavat modifitseerimist teostada.

Ühtlasena tajutud hääle puhul võib spektraalse ühtluse asemel olla oluline hoopis vokaaltrakti kuju muutumatus (nt kui ülesandeks on laulda samal vokaalil erinevaid helikõrgusi). Vokaalide nn katmist või modifitseerimist hääle kõrgenemisel on käsitletud ka teadliku vastuseisuna reflektoorsele püüdele jääda esimese formandiga häälestatuks ühele ja samale tõusvale osahelile (mis väljendub laulmises järjest rohkem avaneva suuga), kuid mis samal ajal tekitab meeshäälte puhul kisale sarnase nn valge hääle (Bozeman 2013). Vokaaltrakti kuju püsimine ühesugusena helikõrguse muutumisel põhjustab teisest küljest aga osahelide tugevusvahekorra puht-akustilistel põhjustel toimuvaid muutusi (nt LF1 graafiku "lainetamist", mis oli iseloomulik lauljate K ja H sooritusele ja mis sisuliselt on hääletämbri varieerumine).

Lõpuks arutleme ja teeme oletusi selle kohta, mille poolest oleks puht-akustiliste faktorite mõju kujunenud teistsuguseks, kui ülesannetes oleks kasutatud mõnd teist vokaali ja kui ülesande helistik (st helikõrguslik ala) oleks olnud teistsugune. Meie töös kasutatud ülesannete puhul oli põhitooni sagedus alati madalam hääliku esimese formandi sagedusest. Vokalistid, eriti kui nende hääleliik on kõrge, nt sopranid, metsosopranid või tenorid, peavad aga laulma ka kõrgeid noote, kus põhitooni sagedus osutub kõrgemaks kui F1, mis on tüüpiline kõnehääle puhul. Nii näiteks on tenori kõrge $d o$ puhul põhitooni komponendi sagedus H1 = $523 \mathrm{~Hz}$. Kõnevokaali /i/ puhul on tüüpiline esimese formandi sagedus aga palju madalam - vaid ligikaudu $300 \mathrm{~Hz}$. Sellise põhitooni sageduse ja formantsageduse kombinatsiooni puhul oleks esimesele formandile kõige lähemal paiknev spektripiik põhitooni komponent, ja põhitooni kõrgenemine alas, kus selle sagedus ületab F1 väärtuse, põhjustaks hoopis heli SPL languse, sest spektri kõige tugevam piik (H1) kaugeneks F1-st. Seega, heli kõrgenemise efekt helirõhule oleks vastupidine sellele, mis esines meie töös kasutatud ülesannetes. Nende hüpoteeside kontrollimine empiiriliste eksperimentide abil jääb aga edaspidiseks.

\section{Kokkuvõte}

Käesolevas artiklis uurisime, kas ja kuidas muutuvad lauluhääle spektraalsed parameetrid, mis võiksid olla seotud hääle ühtluse tajumisega, kui klassikaliselt treenitud lauljad täidavad vokaalseid ülesandeid, kus süstemaatiliselt muutub nii hääle kõrgus kui ka dünaamika. Meie hüpoteesiks oli, et lauljad 
püüavad hääle ühtluse parandamiseks kasutada strateegiaid, mis vähendavad vastavate parameetrite varieeruvust.

Kümne meeslaulja vokaalse produktsiooni uurimisel, kus ülesandeks oli laulda vokaalil /a/ $D$-duuris tõusvaid heliredeleid (helikõrguste vahemikus $d$ kuni $d^{1}$ ) nii crescendos kui ka diminuendos, selgus, et keskmiselt muutus lauljaformandi suhteline tugevus (võrreldes esimesele formandile kõige lähemal paikneva spektripiigi tugevusega) nõrgemaks nii siis, kui tuli laulda vaiksemalt, kui ka siis, kui lauljad pidid laulma paari kõige kõrgemat helirea nooti (isegi sel juhul, kui ülesanne oli laulda crescendos). Lauljate keskmine spektri põhitooni suhteline tase (esimesele formandile kõige lähemal paikneva osaheli tugevuse suhtes) oli tugevam, kui madalaid noote lauldi vaikselt. Kui kõrgeid noote lauldi valjult, kaldus põhitooni komponent olema nõrgem. Kõrgete vaikselt lauldud nootide puhul esines küllaltki suur idiosünkraatiline varieeruvus. Akustiliste parameetrite varieerumine oli seotud nii laulja vokaaltehnikast sõltumatute akustiliste faktoritega kui ka laulja poolt tahteliselt reguleeritavate faktoritega.

Nelja katseisiku individuaalse soorituse detailsemal uurimisel selgus, et lauljate käsutuses on strateegiaid, mille eesmärk võib olla häälekõla parema ühtluse saavutamine. Käesolevas uurimuses puudutas see eelkõige viisi, kuidas laulja laulis helirea ülemisi astmekõrgusi. Üks strateegiatest oli piano ja forte eristamine peamiselt lauljaformandi taseme (st tämbrilise) erinevuse, mitte niivõrd hääle helirõhu taseme abil. Teine strateegia seisnes vastupidi lauljaformandi taseme varieerumise vähendamises, samal ajal, kui laulja muutis piano ja forte vahelise erinevuse tekitamiseks hääle kui terviku helirõhu taset. Vastavaid strateegiaid kasutasid siiski vaid mõned lauljad.

\section{Tänuavaldused}

Käesolevat tööd on toetanud Eesti Haridus- ja Teadusministeerium (grant IUT 12-1) ja Euroopa Liit Euroopa Regionaalarengu Fondi (Eesti-uuringute Tippkeskus) kaudu. Autor tänab ka kõiki eksperimendis osalenud lauljaid. 


\section{Kirjandus}

Appelman, Ralph D. 1967. The science of vocal pedagogy: Theory and application. Bloomington: Indiana University Press.

Björkner, Eva \& Sundberg, Johan \& Alku, Paavo 2006. Subglottal pressure and amplitude quotient variation in classically trained baritone singers. Logopedics Phoniatrics Vocology 31 (4), lk 157-165 (doi: 10.1080/14015430600576055).

Björkner, Eva 2008. Musical theatre and opera singing - why so different? A study of subglottal pressure, voice source, and formant frequency characteristics. Journal of Voice 22, lk 533-540 (doi: 10.1016/j.jvoice.2006.12.007).

Bozeman, Kenneth W. 2013. Practical vocal acoustics: Pedagogic applications for teachers and singers. Hillsdale, NY: Pendragon Press.

Christy, Van Ambrose 1967. Expressive singing: a textbook for school or studio class or private teaching. Dubuque, IA: W. C. Brown Co.

Colton, Raymond H. \& Conture, Edward G. 1990. Problems and pitfalls of electroglottography. Journal of Voice 4 (1), lk 10-24 (doi: 10.1016/S0892-1997(05)80077-3).

Fant, Gunnar 1960. Acoustic theory of speech production. The Hague: Mouton.

Gauffin, Jan \& Sundberg, Johan 1989. Spectral correlates of glottal voice source waveform characteristics. Journal of Speech and Hearing Research 32, lk 556-565 (doi: 10.1044/ jshr.3203.556).

Gobl, Christer \& Ni Chasaide, Ailbhe 2012. Voice source variation and its communicative functions. Hardcastle, William \& Laver, John \& Gibbon, Fiona (toim). Handbook of phonetic sciences (2nd edn). Oxford: Wiley, lk 378-423 (doi: 10.1002/9781444317251. ch11).

Gramming, Patricia \& Sundberg, Johan 1988. Spectrum factors relevant to phonetogram measurement. The Journal of the Acoustical Society of America 83, lk 2352-2360 (doi: 10.1121/1.396366).

Granqvist, Svante \& Hertegård, Stellan \& Larsson, Hans \& Sundberg, Johan 2003. Simultaneous analysis of vocal fold vibration and transglottal airflow: exploring a new experimental setup. Journal of Voice 17 (3), lk 319-330 (doi: 10.1067/S08921997(03)00070-5).

Hartmann, William M. 2013. Principles of musical acoustics. New York, NY: Springer.

Heller, Eric J. 2012. Why you hear what you hear: An experiential approach to sound, music and psychoacoustics. Princeton, NJ: Princeton University Press.

Hemsley, Thomas 1998. Singing and Imagination: A Human Approach to a Great Musical Tradition. Oxford: Oxford University Press.

Herbst, Christian T. \& Hess, Markus \& Müller, Frank \& Švec, Jan G. \& Sundberg, Johan 2015. Glottal adduction and subglottal pressure in singing. Journal of Voice 29 (4), lk 391-402 (doi: 10.1016/j.jvoice.2014.08.009). 
Herbst, Christian \& Ternström, Sten 2006. A comparison of different methods to measure the EGG contact quotient. Logopedics Phoniatrics Vocology 31 (3), lk 126-138 (doi: 10.1080/14015430500376580).

Holmberg, Eva B. \& Hillman, Robert \& Perkell, Joseph \& Guiod, Peter \& Goldman, Susan 1995. Comparisons among aerodynamic, electroglottographic, and acoustic spectral measures of female voice. Journal of Speech and Hearing Research 38, lk 1212-1223 (doi: 10.1044/jshr.3806.1212).

Lã, Filipa M. B., \& Sundberg, Johan 2015. Contact quotient versus closed quotient: a comparative study on professional male singers. Journal of Voice 29 (2), lk 148-154 (doi: 10.1016/j.jvoice.2014.07.005).

Miller, Richard 1996. The structure of singing: System and art in vocal technique. New York, NY: Schirmer.

Salomão, Gláucia Laís \& Sundberg, Johan 2008. Relation between perceived voice register and flow glottogram parameters in males. The Journal of the Acoustical Society of America 124 (1), lk 546-551 (doi: 10.1121/1.2924146).

Scearce, Leda 2016. Manual of singing voice rehabilitation: A practical approach to vocal health and wellness. San Diego, CA: Plural Publishing.

Sundberg, Johan 1974. Articulatory interpretation of the "singing formant". The Journal of the Acoustical Society of America 55, lk 838-844 (doi: 10.1121/1.1914609).

Sundberg, Johan 1987. The Science of the Singing Voice. Illinois, IL: Northern Illinois University Press.

Sundberg, Johan 1990. What's so special about singers? Journal of Voice 4 (2), lk 107-119 (doi: 10.1016/S0892-1997(05)80135-3).

Sundberg, Johan 2001. Level and center frequency of the singer's formant. Journal of Voice 15 (2), lk 176-186 (doi: 10.1016/S0892-1997(01)00019-4).

Sundberg, Johan 2013. Perception of singing. Deutsch, Diana (toim). The psychology of music. San Diego, CA: Academic Press, lk 69-105.

Sundberg, Johan \& Titze, Ingo \& Scherer, Ronald 1993. Phonatory control in male singing: a study of the effects of subglottal pressure, fundamental frequency, and mode of phonation on the voice source. Journal of Voice 7 (1), lk 15-29 (doi: 10.1016/S08921997(05)80108-0).

Zhang, Zhaoyan 2016. Mechanics of human voice production and control. The Journal of the Acoustical Society of America 140 (4), lk 2614-2635 (doi: 10.1121/1.4964509).

Titze, Ingo R. 1992. Acoustic interpretation of the voice range profile (phonetogram). Journal of Speech and Hearing Research 35 (1), lk 21-34 (doi: 10.1044/jshr.3501.21).

Titze, Ingo R. 1994. Principles of voice production. Englewood Cliffs, NJ: Prentice-Hall.

Titze, Ingo R. \& Abbott, Katherine Verdolini 2012. Vocology: The science and practice of voice habilitation. Salt Lake City, UT: The National Center for Voice and Speech.

Vurma, Allan 2017. Phonatory strategies of male vocalists in singing diatonic scales with various dynamic shapings. Journal of Voice 31 (2), lk 254.e17-254.e29 (doi: 10.1016/j. jvoice.2016.06.018). 


\title{
Summary
}

\section{The stability of voice source spectral envelope in singing scales with varying dynamics}

\author{
Allan Vurma \\ Senior Researcher, Estonian Academy of Music and Theatre \\ vurma@ema.edu.ee
}

Keywords: classical singing, evenness of the voice, glottography, inverse filtering, singer's formant, spectral analysis, voice dynamics

The aim of the present work was to investigate whether and how the timbre-related voice parameters change when classically trained vocalists sing vocal tasks with varying voice dynamics and pitch. This research question was motivated by a standpoint often expressed in literature that one of the goals of classical voice training is the evenness of the sound. In the empirical experiment we asked ten male vocalists (opera and oratorio soloists, and voice students) to sing one-octave ascending $D$-major scales (from D3 to D4) in three different ways: (1) with most habitual dynamics without intentional dynamic changes; (2) with sempre crescendo; and (3) with sempre diminuendo. We recorded the performances in a studio with low reverberation. Then we calculated the average power spectrums for each sung note with the help of software Sopran 1.0.10. We determined the levels of the fundamental component and the singer's formant in relation to the level of the strongest peak of the spectrum. We also measured the levels of the sound pressure and the values of the closed quotients and quasi-contact quotients (which characterize the strength of the glottal adduction during phonation). The values of investigated parameters changed systematically during the vocal tasks in the case of all singers. Some of these changes had purely acoustical reasons, which cannot be controlled by the vocal technique of the singer. However, some singers used the strategies, the aim of which was probably the improvement of the perceived evenness of the voice. One of such strategies was the creation of difference between the piano and forte dynamics mainly by changing the timbre and not so much by altering the sound pressure level of the voice. The opposite strategy was the changing of the sound level while keeping the variability of the relative level of the singer's formant small (which characterizes the brightness and carrying power of the voice). The perceived evenness of the voice may also depend on some other voice properties that we did not address in this work. The pattern of changes in the voice parameters may also depend on the used vowels and pitch range. 